\title{
Drivers of hemispheric differences in return dates of mid-latitude stratospheric ozone to historical levels
}

\author{
H. Garny ${ }^{1}$, G. E. Bodeker ${ }^{2}$, D. Smale ${ }^{3}$, M. Dameris ${ }^{1}$, and V. Grewe ${ }^{1}$ \\ ${ }^{1}$ Deutsches Zentrum für Luft- und Raumfahrt, Institut für Physik der Atmosphäre, Oberpfaffenhofen, Germany \\ ${ }^{2}$ Bodeker Scientific, Alexandra, New Zealand \\ ${ }^{3}$ NIWA (National Institute of Water and Atmospheric Research) Lauder, Lauder, New Zealand \\ Correspondence to: H. Garny (hella.garny@dlr.de)
}

Received: 18 October 2012 - Published in Atmos. Chem. Phys. Discuss.: 19 December 2012

Revised: 24 May 2013 - Accepted: 19 June 2013 - Published: 1 August 2013

\begin{abstract}
Chemistry-climate models (CCMs) project an earlier return of northern mid-latitude total column ozone to 1980 values compared to the southern mid-latitudes. The chemical and dynamical drivers of this hemispheric difference are investigated in this study. The hemispheric asymmetry in return dates is a robust result across different CCMs and is qualitatively independent of the method used to estimate return dates. However, the differences in dates of return to 1980 levels between the southern and northern midlatitudes can vary between 0 and $30 \mathrm{yr}$ across the range of CCM projections analyzed. Positive linear trends in ozone lead to an earlier return of ozone than expected from the return of $\mathrm{Cl}_{\mathrm{y}}$ to 1980 levels. This forward shift is stronger in the Northern than in the Southern Hemisphere because (i) trends have a larger effect on return dates if the sensitivity of ozone to $\mathrm{Cl}_{\mathrm{y}}$ is lower and (ii) the trends in the Northern Hemisphere are stronger than in the Southern Hemisphere. An attribution analysis performed with two CCMs shows that chemically-induced changes in ozone are the major driver of the earlier return of ozone to 1980 levels in northern midlatitudes; therefore transport changes are of minor importance. This conclusion is supported by the fact that the spread in the simulated hemispheric difference in return dates across an ensemble of twelve models is only weakly related to the spread in the simulated hemispheric asymmetry of trends in the strength of the Brewer-Dobson circulation. The causes for chemically-induced asymmetric ozone trends relevant for the total column ozone return date differences are found to be (i) stronger increases in ozone production due to enhanced $\mathrm{NO}_{\mathrm{x}}$ concentrations in the Northern Hemisphere lowermost stratosphere and troposphere, (ii) stronger decreases in the
\end{abstract}

destruction rates of ozone by the $\mathrm{NO}_{\mathrm{x}}$ cycle in the Northern Hemisphere lower stratosphere linked to effects of dynamics and temperature on $\mathrm{NO}_{\mathrm{x}}$ concentrations, and (iii) an increasing efficiency of heterogeneous ozone destruction by $\mathrm{Cl}_{\mathrm{y}}$ in the Southern Hemisphere mid-latitudes as a result of decreasing lower stratospheric temperatures.

\section{Introduction}

In support of the WMO/UNEP (World Meteorological Organization/United Nations Environmental Programme) ozone assessment 2010 (WMO, 2011), the SPARC (Stratospheric Processes And their Role in Climate) CCMVal-2 activity coordinated simulations of the future evolution of atmospheric ozone using about a dozen chemistry-climate models (CCMs). These simulations have been extensively analyzed and evaluated (SPARC-CCMVal, 2010). As a result of the success of the Montreal Protocol and its amendments and adjustments, tropospheric concentrations of ozone depleting substances (ODSs) are decreasing (Montzka et al., 1999) and are expected to continue to decrease over the next century. In mid-latitudes, stratospheric $\mathrm{Cl}_{\mathrm{y}}$ is projected by $\mathrm{CCMs}$ to return to 1980 levels by the middle of the 21 st century. Total column ozone (TOZ), on the other hand, is projected by CCMs to return to 1980 values earlier: by the early 2020 s over northern mid-latitudes and by the mid-2030s over southern mid-latitudes (Austin et al., 2010; Eyring et al., 2010). Unlike $\mathrm{Cl}_{\mathrm{y}}$ where the return to 1980 values is hemispherically symmetric (Austin et al., 2010), the return of TOZ 
to 1980 values is hemispherically asymmetric. In Austin et al. (2010) and Oman et al. (2010) it was shown that this hemispheric asymmetry results from changes in lower stratospheric ozone, specifically ozone below $20 \mathrm{hPa}$.

In addition to being influenced by ozone depleting substances (ODSs), ozone concentrations are also affected by changes in greenhouse gas (GHG) concentrations. While ODS concentrations increased strongly in the second half of the 20th century, and are expected to decline again in the 21st century, GHG concentrations are projected to keep rising monotonically. Eyring et al. (2010) used a multi-model set of sensitivity simulations, in which either ODS or GHG concentrations were held constant, to show that the hemispheric difference in mid-latitude ozone evolution is due to a stronger response of Northern Hemisphere (NH) ozone to increasing GHG concentrations compared to its Southern Hemisphere (SH) counterpart.

A number of processes determine the response of midlatitude ozone to increasing GHG concentrations. In the upper stratosphere, increasing GHG concentrations cause temperatures to decrease which slows the $\mathrm{O}+\mathrm{O}_{3} \rightarrow 2 \mathrm{O}_{2}$ reaction such that ozone increases (Portmann and Solomon, 2007). Increases in the concentrations of $\mathrm{N}_{2} \mathrm{O}$ and $\mathrm{CH}_{4}$ elevate the concentrations of the ozone precursors $\mathrm{NO}_{\mathrm{x}}(=$ $\left.\mathrm{NO}+\mathrm{NO}_{2}\right)$ and $\mathrm{HO}_{\mathrm{x}}\left(=\mathrm{H}+\mathrm{OH}+\mathrm{HO}_{2}\right)$. However, the response of ozone to changes in $\mathrm{N}_{2} \mathrm{O}$ and $\mathrm{CH}_{4}$ depends on a number of coupled processes. For example, the ratio of $\mathrm{NO}_{\mathrm{x}}$ to $\mathrm{N}_{2} \mathrm{O}$ is temperature-dependent, such that decreasing temperatures lower the yield of $\mathrm{NO}_{x}$ from $\mathrm{N}_{2} \mathrm{O}$ (Plummer et al., 2010; Revell et al., 2012b). The speed and path of air parcels through the Brewer-Dobson Circulation (BDC) also affects $\mathrm{NO}_{\mathrm{x}}$ concentrations by determining the time available for photolysis of $\mathrm{N}_{2} \mathrm{O}$ (Cook and Roscoe, 2012). Since CCMs consistently project a strengthening of the BDC (Butchart et al., 2010), this will also reduce the yield of $\mathrm{NO}_{\mathrm{x}}$ from $\mathrm{N}_{2} \mathrm{O}$ (Cook and Roscoe, 2012).

In previous studies, the hemispheric asymmetry in the response of ozone to increasing GHG concentrations was attributed to hemispheric asymmetries in changes in transport; the strength of the BDC is projected to increase more in the NH compared to the SH (WMO, 2011; Eyring et al., 2010; Austin et al., 2010). However, little evidence has been presented to support this hypothesis. In this study, the role of changes in transport on the hemispheric asymmetry of return dates of mid-latitude ozone to 1980 levels is reassessed. Two complementary approaches are followed: first, a multi-model ensemble of CCMVal-2 models is used to investigate the robustness of projections of the temporal evolution of ozone, and then two CCMs (described in Sect. 2) that incorporate the necessary diagnostics are used to conduct a detailed attribution of the drivers of mid-latitude ozone changes through the 21 st century. These diagnostics, along with other methods used in the analysis, are described in Sect. 3. In Sect. 4, the multi-model analysis is presented, testing the consistency of the hemispheric asymmetry in return dates across models, evaluating the height dependence of the hemispheric differences and testing their connections to changes in the BDC. Based on two of the CCMs, an attribution is performed, allowing an explicit separation of the effects of chemistry and transport (Sect. 5). The chemically-induced ozone changes and their drivers are analyzed in more detail in Sect. 6. Uncertainties and the relevance of the processes found are discussed in Sect. 7. Conclusions are presented in Sect. 8.

\section{Chemistry-climate models}

Within CCMVal-2 (SPARC-CCMVal, 2010) a set of simulations was performed with a number of CCMs aiming at investigating the stratospheric ozone layer. Our analysis requires seamless simulations from the past to the future, and the necessary output of these simulations was available from 12 CCMs. The individual models are not identified as this is not required for the analyses that aim to explore the spread in the simulations rather than the performance of individual models. A description of models and the simulation setups can be found in Morgenstern et al. (2010). For 10 of the models, REF-B2 simulations are analyzed. The REF-B2 simulations are designated to consistently simulate past and future climate, extending from 1960 to 2100, and include anthropogenic forcing by GHG and ODS emissions. The GHG emissions follow the Special Report on Emissions Scenarios (SRES) A1B scenario. The SCN-B2d simulation, used for the remaining two models, differs from REF-B2 in that it includes natural variability, i.e., the solar cycle and the QBO (quasi-biennial-oscillation) (see Eyring et al., 2008). However, for the purposes of this study, the two simulations are equivalent.

Two CCMs that are equipped with the necessary diagnostics are used more extensively for the attribution analysis and are described in greater detail below.

\subsection{NIWA-SOCOL}

The NIWA-SOCOL (National Institute of Water and Atmospheric Research - SOlar Climate Ozone Links) CCM is a modified version of the CCM SOCOL_v2.0 (Schraner et al., 2008) in which stratospheric ozone is simulated, including a budget analysis of ozone production, loss from different catalytic cycles and transport. SOCOL comprises the MAECHAM4 global climate model and a modified version of the chemistry transport model MEZON (Egorova et al., 2003). MAECHAM4 is configured with a T30 spectral horizontal resolution with 39 vertical levels between Earth's surface and $0.01 \mathrm{hPa}(\sim 80 \mathrm{~km})$. A hybrid transport scheme is employed to advect the chemical constituents. The chemical solver algorithm uses a Newton-Raphson iterative method, taking into account 41 chemical species, 140 gasphase reactions, 46 photolysis reactions and 16 heterogeneous reactions. 
The output used in this study originates from a NIWASOCOL REF-B2 simulation. This simulation is an updated version of the one performed for the SPARC CCMVal-2 activity in that the sea surfaces temperatures (SSTs) simulated by ECHAM5-MPI-OM are used. Otherwise the boundary conditions are as described in Morgenstern et al. (2010) and are consistent with the CCMVal-2 specifications. In the NIWA-SOCOL simulation, a minor error was made in the prescription of the $\mathrm{NO}_{\mathrm{x}}$ boundary condition, i.e., aircraft $\mathrm{NO}_{\mathrm{x}}$ emissions were inadvertently doubled. However, since NIWA-SOCOL is used to study ozone changes mostly above $100 \mathrm{hPa}$, this error is not expected to impact the results.

A diagnostic implemented within the model tracks the change in the ozone concentration within each model grid cell, at each time step, resulting from net chemical production and net transport into the cell. The change in net chemical production is calculated explicitly, and can be further attributed to different catalytic cycles. Further attribution of odd oxygen $\left(\mathrm{O}+\mathrm{O}_{3}\right)$ production, via the Chapman cycles, and destruction by the $\mathrm{HO}_{\mathrm{x}}, \mathrm{NO}_{\mathrm{x}}$ and $\mathrm{Cl}_{\mathrm{y}}$ cycles, across 15 different catalytic cycles, was performed within the model chemistry scheme using the rate limiting steps of the corresponding reaction cycles. This diagnostic, along with the detailed list of reaction cycles, is described in Revell et al. (2012b). In this paper, destruction by brominecontaining species is included in the $\mathrm{Cl}_{\mathrm{y}}$ destruction term. The change in ozone due to transport is defined as the residual of the net chemical production subtracted from the total ozone change. Both terms are recorded and accumulated into monthly means for each grid cell. Since transport is determined as a residual, any numerical computation residual and renormalization of the ozone concentrations are folded into the transport term.

\subsection{E39CA}

The CCM ECHAM4.L39(DLR)/CHEM/ATTILA (E39CA) is an updated version of ECHAM4.L39(DLR)/CHEM (E39C) (Hein et al., 2001; Dameris et al., 2005) with the former semi-Lagrangian advection scheme replaced by the fully Lagrangian advection scheme ATTILA (Reithmeier and Sausen, 2002; Stenke et al., 2009). E39C is based on the spectral general circulation model ECHAM4.L39(DLR) (Land et al., 2002) and the chemistry-module CHEM (Steil et al., 1998). The model is run with a spectral horizontal resolution of $\mathrm{T} 30$, corresponding to $\sim 3.75^{\circ} \times 3.75^{\circ}$ on a transformed latitude-longitude grid. The model consists of 39 layers in the vertical, extending from the surface to the uppermost layer centered at $10 \mathrm{hPa}$. The chemistry module CHEM is based on a generalized family concept and includes homogeneous and stratospheric heterogeneous ozone chemistry and the most relevant chemical processes for describing tropospheric background chemistry. Ozone depletion cycles involving bromine were originally not implemented in the CHEM module, but subsequently a parame- terization for the bromine chemistry was included. The parameterization is based on the photolysis of $\mathrm{Cl}_{2} \mathrm{O}_{2}$ and described in detail in Stenke et al. (2009). Boundary conditions for the two families $\mathrm{Cl}_{\mathrm{x}}\left(=\mathrm{HCl}+\mathrm{ClONO}_{2}+\mathrm{ClO}_{\mathrm{x}}\right)$ and $\mathrm{NO}_{\mathrm{y}}\left(=\mathrm{NO}_{\mathrm{x}}+\mathrm{HNO}_{3}\right)$ are prescribed at the uppermost model level $(10 \mathrm{hPa})$ to account for chemical processes above the model top. For a more detailed description of E39CA, see Stenke et al. (2009). The SCN-B2d simulation performed with E39CA, as submitted to the CCMVal-2 archives, is used here. The simulation extends from 1960 to 2049, and the boundary conditions including anthropogenic and natural forcings are described in Garny et al. (2009).

As in NIWA-SOCOL, ozone production and destruction rates from a prescribed set of chemical reaction cycles are calculated from the rate-limiting reaction steps, and are saved as part of the model output. The total chemical tendencies of ozone are then calculated off-line from the sum of the tendencies of the chemical cycles. The transport tendencies are calculated by subtracting the ozone chemical tendencies from the total ozone tendencies. Thus, transport tendencies are calculated as residuals in both models: in NIWA-SOCOL online during the simulation and in E39CA off-line after the simulation was performed. Therefore, transport tendencies include in both models any spurious contributions to ozone tendencies resulting from numerical artifacts within the model. Excessive diffusion due to the numerical representation of advection is thus also part of the transport tendency, as it should be since it is part of ozone transport in the models.

Chemical reaction cycles are grouped, as in NIWASOCOL, into production by the Chapman cycle, and destruction by the $\mathrm{HO}_{\mathrm{x}}, \mathrm{NO}_{\mathrm{x}}$ and $\mathrm{Cl}_{\mathrm{y}}$ cycles. As mentioned above, any bromine-related ozone destruction is included in the $\mathrm{Cl}_{\mathrm{y}}$ loss term. Additionally, in E39CA the rate-limiting reaction rates of two of the main tropospheric ozone production cycles are saved as output. These rate-limiting reactions are (1) $\mathrm{HO}_{2}+\mathrm{NO} \rightarrow \mathrm{OH}+\mathrm{NO}_{2}$ (in the following referenced as "PHN") and (2) $\mathrm{CH}_{3} \mathrm{O}_{2}+\mathrm{NO} \rightarrow \mathrm{CH}_{3} \mathrm{O}+\mathrm{NO}_{2}$ (referenced as "PCN"). Dry deposition at the surface is also considered for the budget calculation.

\section{Methods}

In this study, return dates of ozone to historical values are estimated using a linear regression approach, as described in the following in Sect. 3.1. Apart from providing a smooth time series that is needed for the return date calculation, the regression model is used for the statistical separation between that part of each time series that is congruent with the evolution of $\mathrm{Cl}_{\mathrm{y}}$ and that part that is congruent with a linear trend. The linear trend is responsible for driving ozone return dates away from the return dates of $\mathrm{Cl}_{\mathrm{y}}$. We argue that the trends are responsible for the hemispheric asymmetric return dates (see Sect. 4.1). The physical processes responsible for the trends are further analyzed in Sect. 5. A method is used 
that attributes ozone changes to changes in chemistry and transport (described in Sect. 3.2). Thus, the ozone trends can be separated into chemically-induced and transport-induced ozone trends.

\subsection{Estimation of return dates}

To estimate dates of return of ozone to 1980 levels, the time series need to be smoothed to remove the effects of unforced (internal) variability that would otherwise make the return date evaluation susceptible to climate noise. For the analysis in support of the 2010 Ozone Assessment (WMO, 2011), a time-series adaptive model analysis (TSAM) method (Scinocca et al., 2010) was used. This method separates the time series into a smooth signal and superimposed noise, based on a statistical non-parametric fit. An alternative approach is to iteratively smooth the time series by applying a $1: 2: 1$ filter many times. A comparison of the TSAM method with the iterative $1: 2: 1$ smoothing can be found in the supplement to Chapter 9 of the SPARC CCMVal-2 report (SPARC-CCMVal, 2010). This comparison shows that the multi-model mean estimate of mid-latitude ozone return dates is independent of the method used. For individual models, on the other hand, the choice of the method can lead to large differences in the return dates.

A conceptually different approach to separating the signal from the noise is to apply a linear least squares regression model with given geophysical predictors, i.e., using a priori information on the known drivers of the long-term changes in ozone. In practice, these predictors are the burden of $\mathrm{Cl}_{\mathrm{y}}$ (known to be the cause of large depletion of ozone) and a linear trend, which is assumed to approximately represent the response to changes in GHG concentrations and other emissions that increase monotonically (e.g., $\mathrm{NO}_{\mathrm{x}}$ emissions at the surface). Thus, the regression model is of the form

$\mathrm{O}_{3}(t)=a_{0}+a_{1} \times \mathrm{Cl}_{\mathrm{y}}(t)+a_{2} \times t+R(t)$,

where $a_{0}, a_{1}$ and $a_{2}$ are the offset, the $\mathrm{Cl}_{\mathrm{y}}$ and the trend regression coefficients, respectively, and $R$ is the residual. More details can be found in Appendix A. While this regression approach might be criticized for assuming ozone to be driven only by $\mathrm{Cl}_{\mathrm{y}}$ or some linear process, it has the advantage of permitting a separation between these two terms. In particular, if the goal is to understand the deviation of ozone return dates from $\mathrm{Cl}_{\mathrm{y}}$ return dates, the regression performed in this way separates the secular evolution of ozone into a component that is congruent with the $\mathrm{Cl}_{\mathrm{y}}$ evolution (i.e., returns to 1980 values when $\mathrm{Cl}_{\mathrm{y}}$ does) and a component that drives deviations away from the $\mathrm{Cl}_{\mathrm{y}}$ return dates. This physical interpretation of the regression model attribution between its two basis functions requires a sufficiently long time series so that the $\mathrm{Cl}_{\mathrm{y}}$ and linear trend basis functions are approximately orthogonal. This is achieved by considering the 1960 to 2049 period. The fitted time series from this regression model that attributes ozone changes to $\mathrm{Cl}_{\mathrm{y}}$ and the linear trend term is then used to estimate return dates to 1980 values. As shown in Appendix A, this method of calculating return dates gives similar results to other methods; thus the overall results are independent of the method used for the return date estimation.

Dates of return of TOZ to 1980 values in the mid-latitudes $\left(45-60^{\circ}\right)$ of both hemispheres for twelve different CCMs are shown in Fig. 1. Compared to earlier estimates (Austin et al., 2010; Eyring et al., 2010), the multi-model mean return dates derived here are slightly earlier in both hemispheres. This might result from a different choice of the geographical region (60 to $45^{\circ} \mathrm{N}$ as opposed to $35^{\circ} \mathrm{N}$ ), for reasons explained later, or from a different subset of CCMs used here. However, the 10 to $15 \mathrm{yr}$ earlier return of northern mid-latitude TOZ to 1980 values compared to southern mid-latitude TOZ is in close agreement with estimates by Austin et al. (2010) and Eyring et al. (2010).

\subsection{Ozone attribution method}

Ozone changes are attributed to sources and sinks (chemical production and loss and transport of ozone) as described in Garny et al. (2011). A short summary of the method is given in the following. The required model output are the chemical ozone tendencies (the total ozone production and the total ozone destruction). In Garny et al. (2011), changes in ozone between two time periods were attributed to changes in chemical production, destruction and transport. It was assumed that the annual mean ozone tendencies, averaged over the period of interest, were close to zero. Here, this method is extended so that it can be applied to time series of ozone, i.e., the method attributes year-to-year changes to changes in the sink and source terms.

The ozone budget equation for the annual mean change in ozone for two periods $p 1$ and $p 2$ is the following (see Eq. 4 of Garny et al., 2011):

$$
\begin{aligned}
& {\left[\frac{\partial \mathrm{O}_{3}}{\partial t}\right]^{p_{1}}=[P]^{p_{1}}-\left[D \mathrm{O}_{3}\right]^{p_{1}}+[T]^{p_{1}}} \\
& {\left[\frac{\partial \mathrm{O}_{3}}{\partial t}\right]^{p_{2}}=[P]^{p_{2}}-\left[D \mathrm{OO}_{3}\right]^{p_{2}}+[T]^{p_{2}} .}
\end{aligned}
$$

The integration denoted by [.] is the integral over the time periods $p_{1}$ and $p_{2}$, respectively. $\mathrm{O}_{3}$ is the ozone mixing ratio within some model grid cell, $P$ is the ozone production within the grid cell, and $D$ is the fraction of the ozone destroyed in that time step within the grid cell. $T$ is the net amount of ozone transported into or out of the grid cell. In contrast to Garny et al. (2011), the term $\left[\frac{\partial \mathrm{O}_{3}}{\partial t}\right]$ is not assumed to be zero, allowing periods to be a single year. 

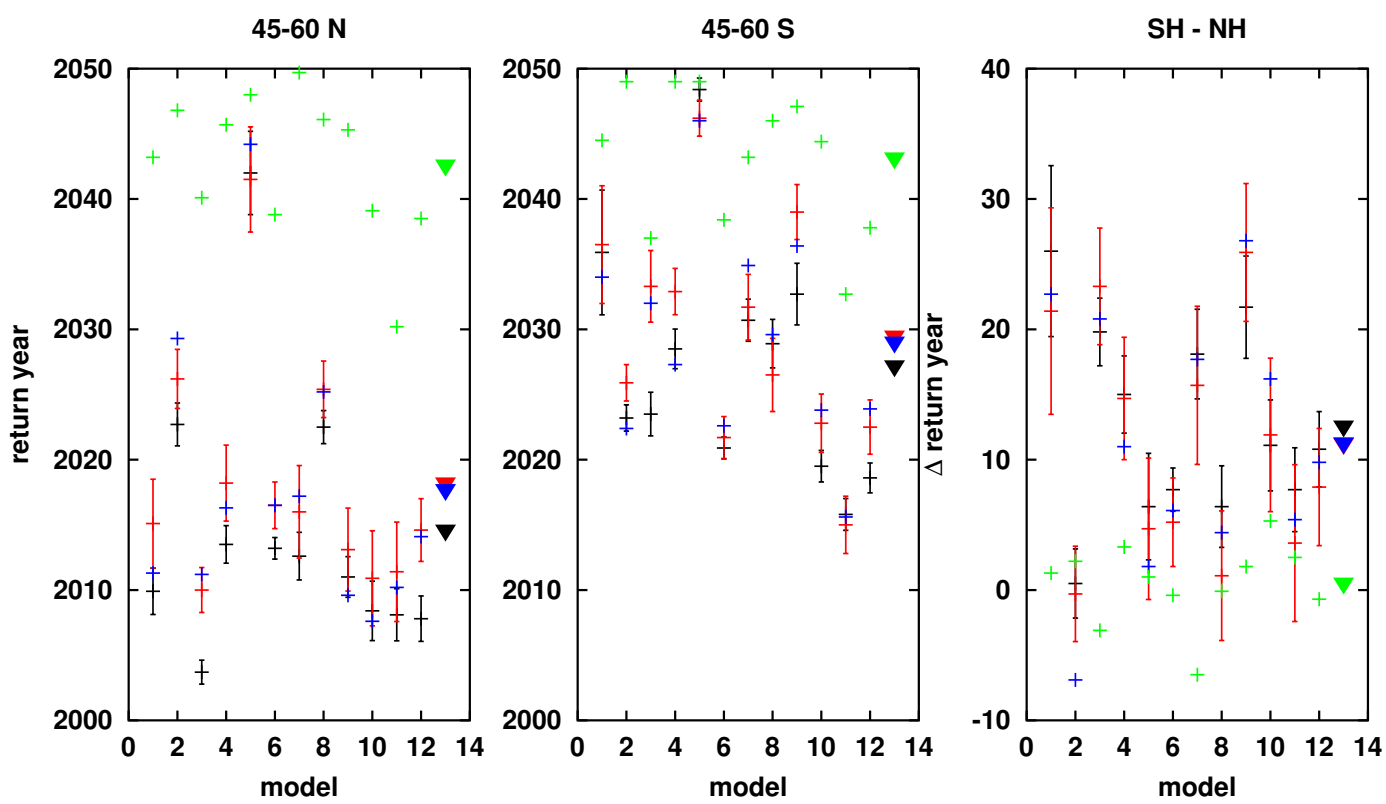

Fig. 1. Return dates to 1980 values of mid-latitude total column ozone for twelve different CCMs using a simple regression (black, with uncertainties), using advanced regression (red, with uncertainties) and smoothing (blue) together with $50 \mathrm{hPa} \mathrm{Cly} \mathrm{return} \mathrm{dates} \mathrm{(green).}$ Triangles on the right are the multi-model mean. Left panel: $\mathrm{NH}$ mid-latitudes $\left(45-60^{\circ} \mathrm{N}\right)$, middle: $\mathrm{SH}$ mid-latitudes $\left(45-60^{\circ} \mathrm{S}\right)$ and right: $\mathrm{SH}-\mathrm{NH}$.

For $\left[D \mathrm{O}_{3}\right] \approx[D]\left[\mathrm{O}_{3}\right]$, the equations above can be transformed to describe the relative change in ozone as

$$
\underbrace{\frac{\left[\mathrm{O}_{3}\right]^{p_{2}}-\left[\mathrm{O}_{3}\right]^{p_{1}}}{\left[\mathrm{O}_{3}\right]^{p_{1}}}}_{\text {relative ozone change }}=\underbrace{\frac{[D]^{p_{1}}-[D]^{p_{2}}}{[D]^{p_{2}}}}_{\text {Destruction-induced } \mathrm{O}_{3} \text { change }}
$$$$
+\underbrace{\frac{[P]^{p_{2}}-[P]^{p_{1}}}{[P]^{p_{1}}+[T]^{p_{1}}-[\Delta]^{p_{1}}}}_{\text {Production-induced } \mathrm{O}_{3} \text { change }}+\underbrace{\frac{[T]^{p_{2}}-[T]^{p_{1}}}{[P]^{p_{1}}+[T]^{p_{1}}-[\Delta]^{p_{1}}}}_{\text {Transport-induced } \mathrm{O}_{3} \text { change }}
$$$$
+\underbrace{\frac{[\Delta]^{p_{1}}-[\Delta]^{p_{2}}}{[P]^{p_{1}}+[T]^{p_{1}}-[\Delta]^{p_{1}}}}_{\text {Imbalance term }}+\underbrace{\delta D \times \delta P}_{\text {Nonlinear, chemistry }}
$$$$
+\underbrace{\delta D \times(\delta T+\delta \Delta)}_{\text {Nonlinear, mixed }} .
$$

The first three terms on the right-hand side of the equation are the contributions to ozone changes due to changes in destruction, production and transport, respectively. $\Delta$ is the ozone tendency $\left[\frac{\partial \mathrm{O}_{3}}{\partial t}\right]$ averaged over the respective periods, and the fourth term is therefore the contribution to ozone changes due to a difference in the total gain or loss of ozone over one period compared to the other. Hereafter this is referred to as "imbalance" term. The last two terms in the equation describe the nonlinear contributions, where the $\delta$ denotes the change in ozone due to changes in the respective source or sink, i.e., the first to fourth terms. The nonlinear terms consist of the changes in the destruction rates applied to all other terms (production, transport and the imbalance term). For example, if there is more ozone production from some chemical cycle during a time step, but it is accompanied by an enhanced destruction rate from a different cycle during the same time step, the elevated ozone is immediately subjected to the enhanced destruction, reducing the effect of the additional production. Similarly, stronger transport of ozone into a grid cell might also be mitigated by local changes in the ozone destruction rate, as described by the nonlinear term. The nonlinear terms are one order of magnitude smaller than the other change terms, so as long as changes are small $(<0.1)$, this term is one order of magnitude smaller, and thus not important.

In the analysis presented below, transport and chemicallyinduced ozone changes are separated. The changes due to transport are diagnosed from the third term in Eq. (2). The changes due to chemistry are the sum of the production, destruction and the first nonlinear term (i.e., the first, second and fifth terms in Eq. 2). Hereafter, when referring to the nonlinear term, only the mixed transport-chemistry term (6th term in Eq. 2) is meant.

In Fig. 2, an example of the application of the method is demonstrated for lower stratospheric, partial column, zonal mean ozone at $45^{\circ} \mathrm{S}$ from 1960 to 2049 . Ozone changes in each year $\left(=p_{2}\right)$ are calculated relative to the mean over 1960-1969 $\left(=p_{1}\right)$, and are reasonably well reproduced by the sum of the terms on the right-hand side of Eq. (2). The 


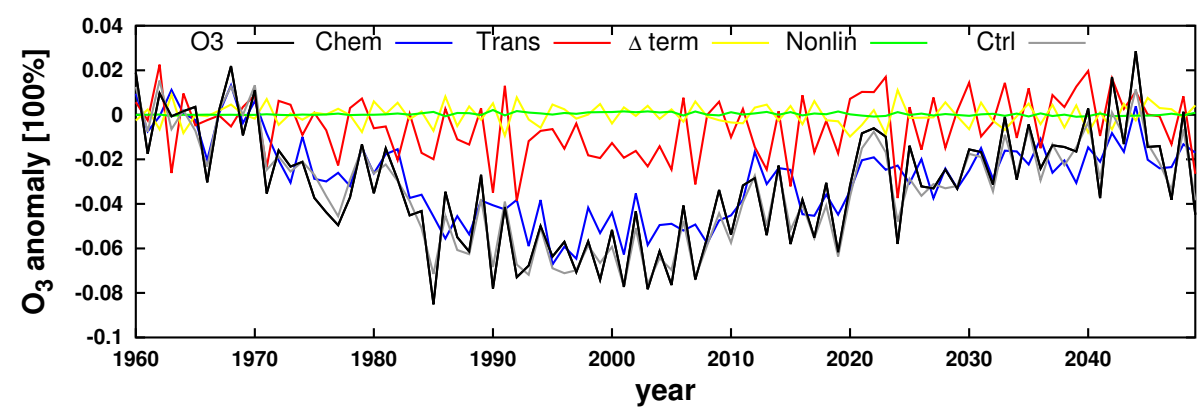

Fig. 2. Demonstration of ozone attribution method: time series of zonal mean lower stratospheric partial column ozone at $45^{\circ} \mathrm{S}$ relative to the mean 1960-1969 (black solid line) as simulated by E39CA, together with changes induced by transport (red), changes induced by chemistry (blue), the imbalance term (yellow), the nonlinear term (green) and the sum of these four terms (control line, grey).

individual components of these terms are shown, indicating the extent to which changes in the respective quantity contribute to the relative change in ozone in a particular year. For example, the red line indicates how much ozone would have changed as a result of changes in transport alone. The largest contributions to ozone changes are from changes in chemistry and transport. The imbalance-term $(\Delta)$ has a minor contribution to interannual variability and none to the longterm decrease in ozone over this period at this location. The nonlinear term has a negligible contribution in this case.

\section{Multi-model analysis}

\subsection{Height dependence of hemispheric difference in return dates}

The dates of return of mid-latitude TOZ to 1980 levels are found to be hemispherically asymmetric in the multi-model mean shown in WMO (2011). Here, we use twelve of the CCMs that were used in the WMO/UNEP ozone assessment to investigate inter-model differences in the asymmetry of the return dates and which altitude regions are primarily responsible for the asymmetry.

Mid-latitude ozone is defined as the area weighted average over the latitude band 45 to $60^{\circ}$ of either hemisphere. This is narrower compared to the WMO (2011) definition of mid-latitude ozone ( 35 to $60^{\circ}$ ). As shown in Sect. 5.2, strengthening of the BDC tends to induce negative ozone trends over low latitudes and positive ozone trends at middle to high latitudes. Because the zero trend in ozone is usually around $45^{\circ} \mathrm{N} / \mathrm{S}$, this is used as the equatorward boundary of the mid-latitudes to minimize any reduction in the diagnosed effects of transport on ozone trends.

The hemispheric differences in return dates of mid-latitude TOZ for the twelve models are shown in the leftmost panel of Fig. 3, calculated from the regression model fit as described in Sect. 3.1. The multi-model mean ozone returns to 1980 levels about $13 \mathrm{yr}$ earlier in the $\mathrm{NH}$ compared to the $\mathrm{SH}$, in agreement with WMO (2011), and this results is robust against using different methods for the return date calculation (see Appendix A). However, there is a large spread in the hemispheric differences among the individual models, ranging from 0 to close to $30 \mathrm{yr}$.

To evaluate the relative contributions of different altitude regions to the hemispheric differences in return dates, partial ozone columns were calculated for (i) the surface to $10 \mathrm{hPa}$, (ii) the tropopause to $10 \mathrm{hPa}$ and (iii) the region from 100 to $10 \mathrm{hPa}$. Thus, the altitude domain of regarded ozone columns is stepwise reduced, excluding first the upper stratosphere, further the troposphere and in a third step also the lowermost stratosphere (i.e., region between the tropopause and $100 \mathrm{hPa}$ ). The upper boundary of the lower stratosphere at $10 \mathrm{hPa}$ was chosen to separate the region where both dynamics and chemistry control ozone from the region where ozone is controlled purely by chemistry (as will be shown for ozone trends in Fig. 10). As shown in Fig. 3, excluding the region above $10 \mathrm{hPa}$ slightly amplifies the hemispheric asymmetry in return dates. As ozone above $10 \mathrm{hPa}$ is primarily chemically controlled and ozone changes tend to be correlated with temperature changes which are generally hemispherically symmetric, including the region above $10 \mathrm{hPa}$ obscures some of the hemispheric asymmetry. Additionally excluding the tropospheric ozone column also has a small effect, in this case slightly reducing the hemispheric asymmetry in return dates. As shown by panel $\mathrm{f}$ in Fig. 3, the hemispheric asymmetry induced by tropospheric ozone shows a large spread between models that even show differences in sign. Given that tropospheric chemistry is treated quite differently, and in many cases rather simplistically in the CCMs, the large spread is not surprising. The contribution of the lowermost stratosphere (LMSTR; hereafter defined as the layer between the tropopause and $100 \mathrm{hPa}$ ), on the other hand, accounts for about half of the hemispheric difference in return dates (the exact contribution depending on the method used to determine the return date). In all but two models, excluding the LMSTR causes the hemispheric differences in return dates to decrease. One might suspect that the time evolution of tropospheric and lowermost stratospheric partial ozone columns 


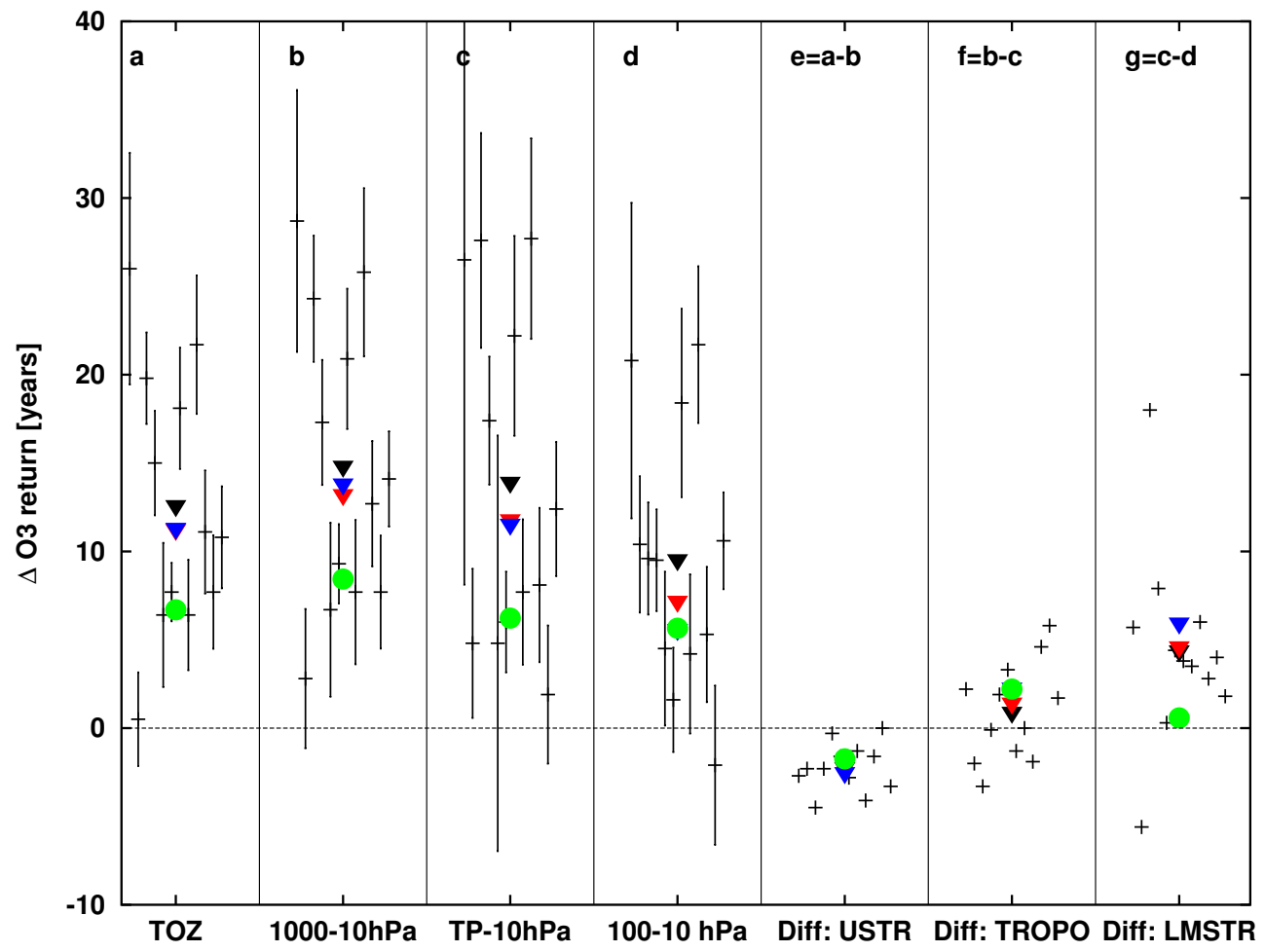

Fig. 3. Hemispheric difference $\left(\left(45\right.\right.$ to $\left.60^{\circ} \mathrm{S}\right)-\left(45^{\circ}\right.$ to $\left.\left.60^{\circ} \mathrm{N}\right)\right)$ in return dates of ozone to 1980 values for twelve different models $($ back crosses with uncertainty bars) and the multi-model mean (triangle) for (a) total column ozone, and partial column ozone (b) from the surface to $10 \mathrm{hPa}$, (c) from the tropopause to $10 \mathrm{hPa}$ and (d) $100 \mathrm{hPa}$ to $10 \mathrm{hPa}$. Furthermore the impact on hemispheric differences in return dates from the upper stratosphere $(\mathbf{e}=\mathbf{a}-\mathbf{b})$, from the tropopause $(\mathbf{f}=\mathbf{b}-\mathbf{c})$ and from the lowermost stratosphere $(\mathbf{g}=\mathbf{c}-\mathbf{d})$ is shown. Multi-model means are also shown for the two additional methods described in Appendix A: method 2 (red) and 3 (blue). The green markers indicate the hemispheric difference in return dates that would result if the linear trend in the NH was the same than in the SH.

are affected by trends in the height of the tropopause. However, when calculating the partial ozone columns with a fixed tropopause at its mean 1960s value, the results on return date differences are unaffected in the multi-model mean. Thus, trends in the tropopause height cannot be made responsible for introducing hemispheric asymmetries in ozone return dates, probably because tropopause trends themselves do not have a strong hemispheric asymmetry. Ozone evolution in the lower stratosphere (LSTR; 100 to $10 \mathrm{hPa}$ ) accounts next to the LMSTR for the other half of the hemispheric difference in the return dates. A large spread between the models is found in the LSTR, and in about half the models the hemispheric difference is only marginally significant when considering the uncertainty resulting from the different methods used to calculate 1980 return dates. These results suggest that it is the LMSTR and LSTR that make the largest contribution to the hemispheric asymmetry in TOZ return dates, in agreement with Oman et al. (2010) and Austin et al. (2010). However, large model-to-model differences and uncertainties in return date estimates exist.

The contributions of ozone at each level to TOZ (i.e., the partial column of ozone over the model layer centered at the respective level) and its response to $\mathrm{Cl}_{\mathrm{y}}$ and the linear trend is shown in Fig. 4. The models agree well in the climatological profile (upper left panel of Fig. 4). The $\mathrm{Cl}_{\mathrm{y}}$ regression coefficients derived for each of the twelve CCMs (middle panel) also agree relatively well, with a negative response of ozone to $\mathrm{Cl}_{\mathrm{y}}$ maximizing at $50 \mathrm{hPa}$. The response of mid-latitude ozone to $\mathrm{Cl}_{\mathrm{y}}$ is stronger in the $\mathrm{SH}$ than in the NH, which is well known (Solomon, 1999). The linear trend (upper right panel) shows significant inter-model differences in both amplitude and vertical structure. Most models show a positive trend in the troposphere; in the multi-model mean the trend is stronger in the NH than in the SH. The multimodel mean trends show a local maximum at $\sim 150 \mathrm{hPa}$. Above this level, trends in both hemispheres decrease with altitude up to $\sim 70 \mathrm{hPa}$. In the $\mathrm{SH}$, about half of the models have a negative ozone trend between 70 and $50 \mathrm{hPa}$. Another local maximum, with positive trends in both hemispheres, is found at $30 \mathrm{hPa}$. Above $30 \mathrm{hPa}$, trends decrease towards zero and become hemispherically symmetric in the multi-model mean. The structure of the trends agrees well with the differences in cumulative ozone columns from the mid-20th to the end of the 21 st century shown by Plummer et al. (2010). They used sensitivity simulations to attribute these trends almost fully to changes in GHG concentrations, thus validating our 

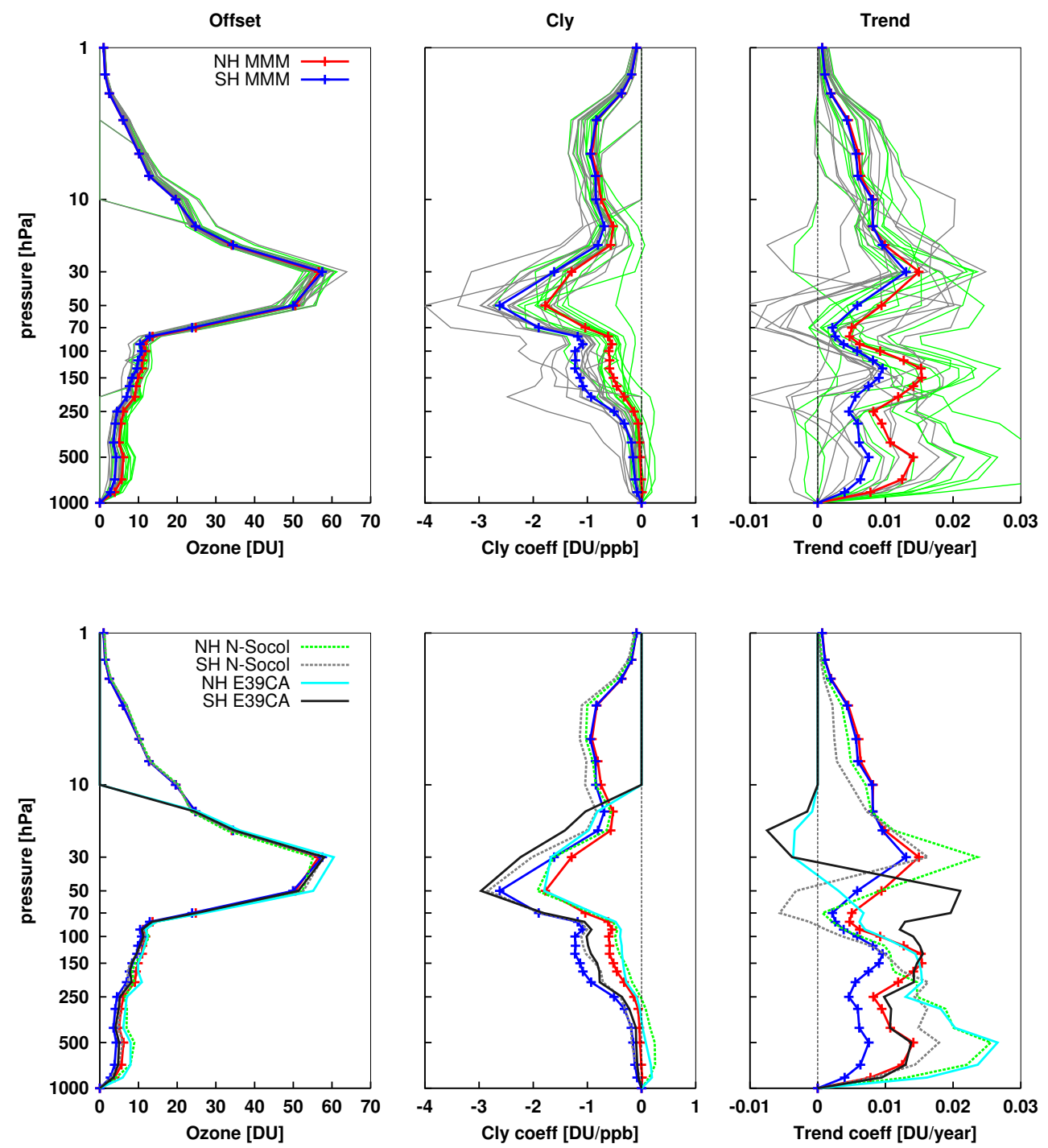

Fig. 4. Profiles of annual mean contribution to TOZ at each level in DU ( $1 \mathrm{DU}=2.69 \times 10^{16}$ molecules $\mathrm{cm}^{-2}$; the sum of the values over all pressure levels equals TOZ. The climatology (left), $\mathrm{Cl}_{\mathrm{y}}$ regression coefficient (middle) and trend coefficient (right) over the period 1960 to 2049 are shown for the multi-model mean of the $\mathrm{NH}$ (red) and the SH (blue) mid-latitudes. Individual models are shown in green for the NH and gray for the SH. The lower panels repeat the multi-model mean from above, and highlight the models NIWA-SOCOL and E39CA (see legend).

method of separating the effects of ODSs and GHGs through linear regression.

How do the linear trends in ozone translate to ozone return dates? If there is no linear trend, ozone returns to 1980 values just when $\mathrm{Cl}_{\mathrm{y}}$ does. Further, if the return dates of $\mathrm{Cl}_{\mathrm{y}}$ are the same in both hemispheres, ozone in the $\mathrm{NH}$ and $\mathrm{SH}$ would also return to its 1980 values at the same time, independent of its sensitivity to $\mathrm{Cl}_{\mathrm{y}}$. As shown in Fig. 1, the multi-model mean $\mathrm{Cl}_{\mathrm{y}}$ returns to 1980 levels at the same time in each hemisphere, and the hemispheric asymmetry in ozone return dates can in none of the models be fully explained by $\mathrm{Cl}_{\mathrm{y}} \mathrm{re}$ turn date differences. If ozone is subject to a positive linear trend, the return date of ozone is shifted forward. However, as illustrated in Fig. 5, the amount by which the return date is shifted depends on the sensitivity of ozone to $\mathrm{Cl}_{\mathrm{y}}$. Therefore, even if linear trends in ozone are the same in the $\mathrm{NH}$ and $\mathrm{SH}$, the return dates to 1980 values can be different. Larger linear trends in the $\mathrm{NH}$ than in the $\mathrm{SH}$, as found for most models (see Fig. 4), cause even larger differences in the ozone return dates between the $\mathrm{NH}$ and $\mathrm{SH}$ (illustrated in the middle panel in Fig. 5). The dependence of the return date on the combination of the $\mathrm{Cl}_{\mathrm{y}}$ and the trend regression coefficient can be expressed in the following way: the ozone anomaly relative to 1980 is described by $\Delta \mathrm{O}_{3}(t)=a_{1} \times \mathrm{Cl}_{\mathrm{y}}(t)+a_{2} \times t$, and thus ozone returns when $t=-a_{1} / a_{2} \times \mathrm{Cl}_{\mathrm{y}}(t)$. Thus, the ratio of the $\mathrm{Cl}_{\mathrm{y}}$ to the trend regression coefficient determines 

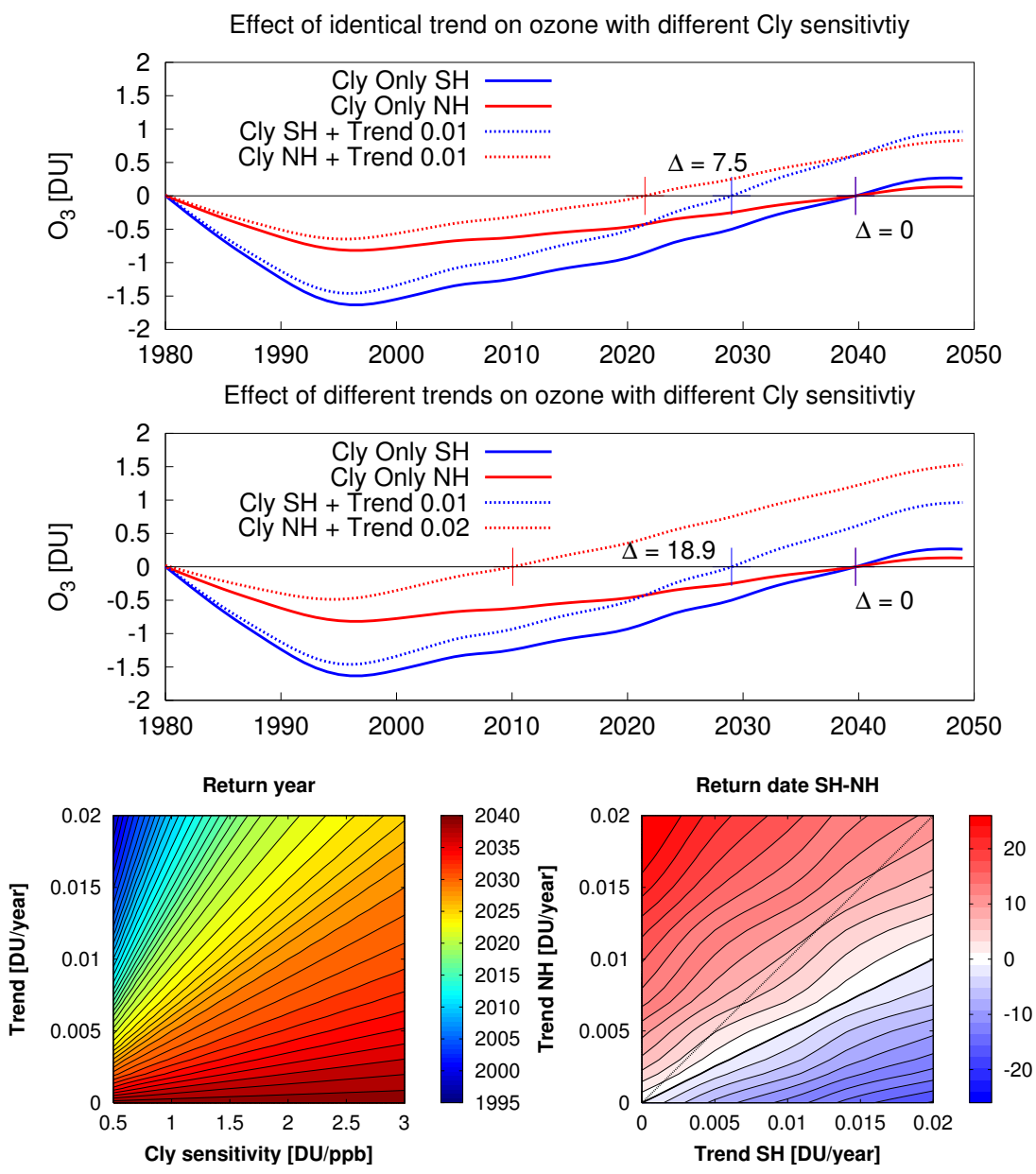

Fig. 5. Schematic of the effect of trends on return dates of ozone to 1980 values. Red and blue lines show ozone time series with different sensitivity to $\mathrm{Cl}_{\mathrm{y}}$, representing the $\mathrm{NH}$ and $\mathrm{SH}$ mid-latitudes. Top: return dates with an identical positive trend in both hemispheres (dotted lines). Middle: return dates with a twice as strong trend in the $\mathrm{NH}$ than in the $\mathrm{SH}$. Bottom left: return dates in dependence of the $\mathrm{Cl}_{\mathrm{y}}$ sensitivity and the trend. Bottom right: differences in return dates of the $\mathrm{NH}$ and $\mathrm{SH}$ as a function of their trends, assuming a sensitivity of ozone to $\mathrm{Cl}_{\mathrm{y}}$ of $1 \mathrm{DU} \mathrm{ppb}^{-1}$ in the $\mathrm{NH}$ and $2 \mathrm{DU} \mathrm{ppb}^{-1}$ in the $\mathrm{SH}$.

the shift of the return dates (see lower left in Fig. 5). As illustrated in the lower right panel in Fig. 5, given a stronger $\mathrm{Cl}_{\mathrm{y}}$ sensitivity in the $\mathrm{SH}$ than in the $\mathrm{NH}$ (assuming 2 and $1 \mathrm{DU} \mathrm{ppb}^{-1}$, respectively), the linear trend in the $\mathrm{NH}$ would need to be smaller than in the $\mathrm{SH}$ by the same ratio (i.e., here 1/2) to result in identical return dates. However, the CCMs simulate a stronger positive trend in NH ozone. Thus, overall both the stronger sensitivity of $\mathrm{SH}$ ozone to $\mathrm{Cl}_{\mathrm{y}}$ and the stronger positive trend in $\mathrm{NH}$ ozone lead to earlier ozone return dates in the $\mathrm{NH}$. The relative role of these effects is quantified by calculating ozone return dates for the $\mathrm{NH}$ assuming that they would be subject to the same (weaker) trend as ozone in the SH. The resulting hemispheric differences in return dates are indicated in Fig. 3 as green markers. These show that the hemispheric differences in ozone return dates would be about half as strong if trends were the same in both hemispheres. Thus, both the different effect of positive trends on return dates in the two hemispheres as well as the hemi- spheric differences in the trends are causing the hemispheric differences in ozone return dates. Therefore, it is important to understand the origin of these linear trends in ozone in both hemispheres. In Sect. 5 the physical drivers of trends will be investigated in detail.

\subsection{Relation of hemispheric differences in the BDC to ozone return dates}

The annual mean downward mass flux in each hemisphere, calculated from the residual circulation stream-function, is used as a measure of the strength of the BDC. The sum of the two hemispheric values is the total downward mass flux, equaling, in absolute value, the total upward mass flux, or tropical up-welling, which is often used to quantify the strength of the BDC. The total downward mass flux in each hemisphere equals the meridional mass flux, which is responsible for transporting ozone from the tropics to mid-latitudes. 


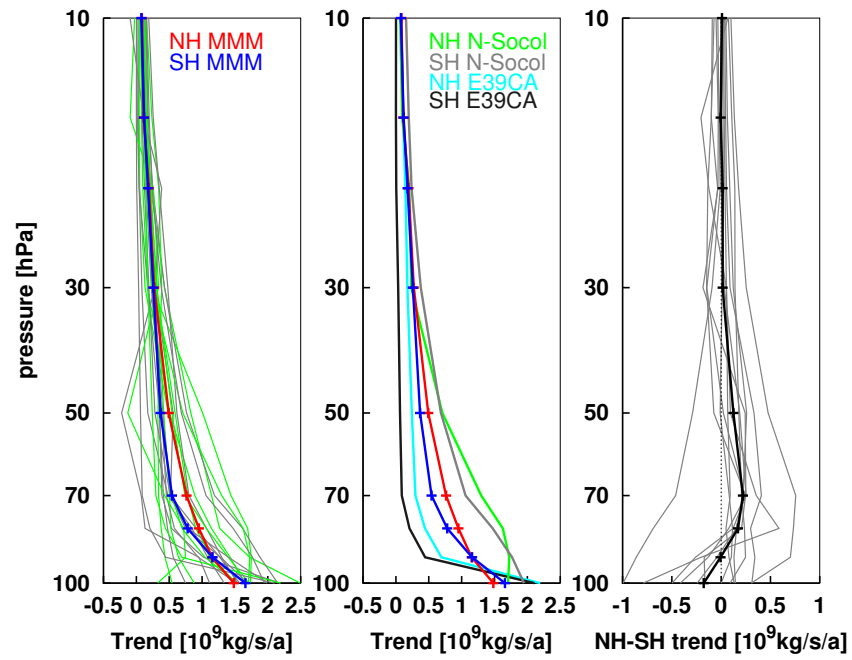

Fig. 6. Profiles of trends in the annual mean residual circulation total downward mass flux in each hemisphere over 1960 to 2049 , individual models and multi-model mean color-coded as in Fig. 4. Right: difference $\mathrm{NH}-\mathrm{SH}$ downward mass fluxes for the multimodel mean (black) and individual models (grey lines).

Trends in total downward mass flux in each hemisphere are shown in Fig. 6 (left) as a function of pressure. The trends are calculated using the same linear regression model as used to calculate the ozone trends. The mass flux increases in both hemispheres and in all models, consistent with the BDC strengthening, as shown by Butchart et al. (2010). The multimodel mean trend in the NH is stronger than in the SH between 90 and $30 \mathrm{hPa}$ (see Fig. 6, right panel). At $100 \mathrm{hPa}$, however, the trend is slightly stronger in the SH than in the $\mathrm{NH}$.

If the hemispheric differences in the strengthening of the BDC were the cause of the hemispheric differences in ozone return dates, it would be expected that in models with a stronger hemispheric difference in the strengthening of the BDC, the hemispheric return dates would show greater separation. The relation between hemispheric differences in the strengthening of the BDC and hemispheric differences in ozone return dates is shown for the set of twelve CCMs in Fig. 7. The LSTR return date differences are plotted against the $70 \mathrm{hPa}$ hemispheric differences in the mass flux trends (i.e., the $70 \mathrm{hPa}$ values shown in Fig. 6 (left); $70 \mathrm{hPa}$ is chosen since the hemispheric difference maximizes there). No statistically significant relationship between hemispheric differences in changes of the BDC and hemispheric differences in return dates are found (the $T$ test value is 0.6 , where significance at the $80 \%$ level is obtained at $T=1.36$ for this sample size). Even when excluding the outlier seen on the lower right of the upper panel of Fig. 7 (with stronger circulation changes in the $\mathrm{SH}$ than $\mathrm{NH}$ ), the correlation is not significant. The LMSTR return date differences are compared with the hemispheric differences in the mass flux trends at
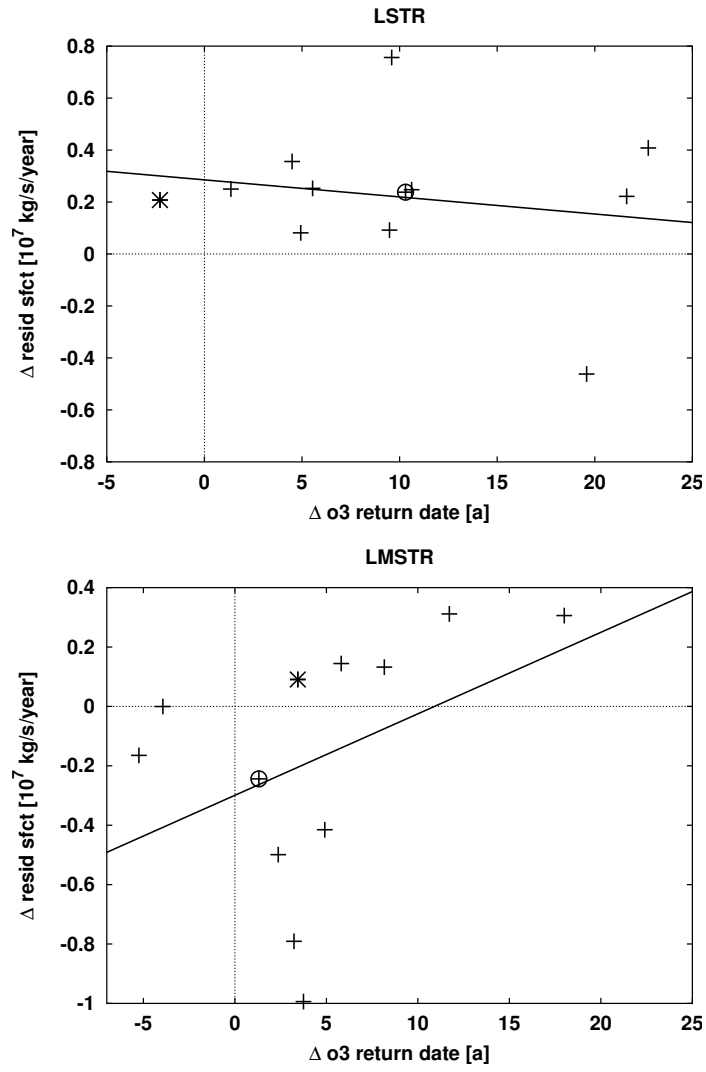

Fig. 7. Top: hemispheric differences $(\mathrm{NH}-\mathrm{SH})$ in the strength of trends in the residual circulation mass flux at $70 \mathrm{hPa}$ plotted against hemispheric differences ( $\mathrm{SH}-\mathrm{NH}$ mid-latitudes) in lower stratospheric return dates for twelve different models (crosses) and their linear fit (line). Bottom: same as above but hemispheric differences in $100 \mathrm{hPa}$ residual circulation mass flux trends against lowermost stratospheric return date differences. The model marked with a circle is NIWA-SOCOL; the model marked with a star is E39CA.

$100 \mathrm{hPa}$ in the lower panel of Fig. 7. In the LMSTR a significant positive correlation at the $80 \%$ significance level is found. While the statistical significance is still rather weak, it provides evidence for some influence of hemispheric asymmetry in BDC changes being responsible for the hemispheric asymmetry in ozone return dates. Half of the models have a negative residual mass flux trend difference, i.e., the $\mathrm{SH}$ mass flux increases more than its $\mathrm{NH}$ counterpart (see also right panel of Fig. 6). The return date differences for five of these models are, however, positive, i.e., return dates in the $\mathrm{NH}$ are earlier than in the SH. This might seem contradictory, however, according to the arguments presented around Fig. 5, a smaller trend in the $\mathrm{NH}$ can still have a larger effect on ozone return dates due to its smaller $\mathrm{Cl}_{\mathrm{y}}$ sensitivity as compared to the $\mathrm{SH}$. Since generally stronger ozone trends can lead to larger hemispheric differences due to their different effects in NH and SH (see Fig. 5, lower panels), one might suspect that the trends in the BDC itself, rather than its hemispheric differences, might correlate better with the 
ozone return date differences. However, this is neither the case in the LSTR or the LMSTR. Overall, these results suggest that other processes than BDC changes play a significant role.

\section{The role of transport and chemistry in driving ozone changes}

The results presented in the previous section suggest that hemispheric differences in the strengthening of the BDC are unlikely to completely explain the hemispheric differences in ozone return dates, as has been previously thought (WMO, 2011). In this section, two CCMs, E39CA and NIWA-SOCOL, each of which incorporate a diagnostic to separate between chemical- and transport-induced changes in ozone (see Sect. 3.2), are used to investigate the processes leading to hemispheric asymmetric ozone trends.

\subsection{Lowermost stratosphere and troposphere}

The E39CA model is suitable for examining the ozone changes in the LMSTR since (i) the model behaves in a similar fashion to the multi-model mean in this region (see Figs. 4 and 6) and (ii) all relevant reaction cycles for this region are saved as output. Unfortunately, the tropospheric reaction cycles are not diagnosed in NIWA-SOCOL; hence only E39CA is used here.

The regression model including $\mathrm{a} \mathrm{Cl}_{\mathrm{y}}$ and linear trend term is applied to the time series of relative deviations of ozone from the 1960s (as shown exemplarily in Fig. 2 for the time series at $45^{\circ} \mathrm{S}$ ). In Fig. 8, the trend coefficient of the regression model applied to mid-latitude ozone (averaged over 45 to $60^{\circ}$ ) is shown as a function of height. The resulting units of the trends are percentage change in ozone per year.

Ozone increases linearly in the LMSTR and troposphere and the trend is stronger in the NH. The chemistry-transport diagnostic allows these trends to be attributed to trends in chemistry (blue lines) and trends in transport (red lines), as calculated using Eq. (2). The nonlinear term (6th term in Eq. 2) is also shown in Fig. 8 and it can be seen that this term becomes relevant only for large values of the chemistry and transport changes, e.g., around $250 \mathrm{hPa}$. The sum of the chemistry, transport and nonlinear term is shown as the control trace (grey line). If this control line deviates from the net ozone trend, the imbalance term becomes important, and the results can no longer be easily interpreted. This occurs when the variability in the time series is large.

As shown in Fig. 8, in both hemispheres, between about 100 and $150 \mathrm{hPa}$, the positive trends in ozone result from positive trends in both transport- and chemicallyinduced changes in ozone. Below $150 \mathrm{hPa}$, changes in chemistry drive a positive trend in ozone which maximizes at around $250 \mathrm{hPa}$. However, the chemically-induced positive trend is largely offset by transport-induced negative
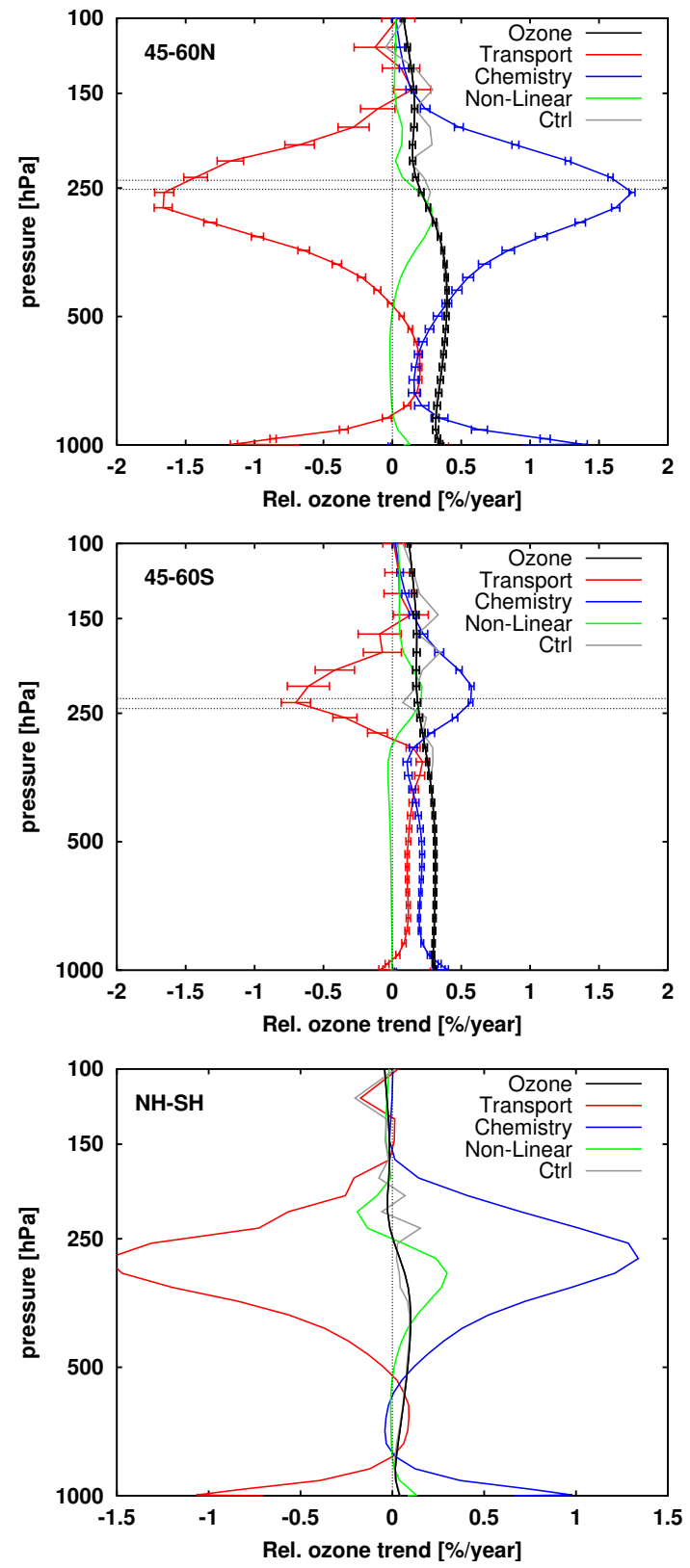

Fig. 8. Profile of relative trends in ozone (in units of \% per year) from E39CA over the period 1960 to 2049 (black). Chemicallyand transport-induced trends in ozone are shown in blue and red, the nonlinear term in green and the sum of these three in grey ("Ctrl"). The black dashed horizontal lines indicate the mean tropopause height in the 1960s (lower line) and 2040s (upper line). Top panel: 45 to $60^{\circ} \mathrm{N}$, middle: 45 to $60^{\circ} \mathrm{S}$, bottom: $\mathrm{NH}-\mathrm{SH}$.

ozone trends. The compensation of chemical effects by transport can be understood as follows: in the mean over the $1960 \mathrm{~s}$, at $250 \mathrm{hPa}$, production (of $0.32 \mathrm{DUmonth}^{-1}$ ) is balanced by transport (of $-0.20 \mathrm{DU} \mathrm{month}^{-1}$ ) and by destruction (of $-0.12 \mathrm{DU}_{\text {month }}{ }^{-1}$ ). Production increases to $0.53 \mathrm{DUmonth}^{-1}$ in the $2040 \mathrm{~s}$, and this increase in 
production is mainly balanced by increased transport away from the source region (i.e., transport decreases to $-0.37 \mathrm{DUmonth}^{-1}$ ), with the remainder balanced by destruction (decreasing to $-0.16 \mathrm{DU}_{\mathrm{month}}{ }^{-1}$ ). Thus, enhanced production leads to more ozone being available at any time step, and therefore more ozone can be transported away from this region leading to a negative effect on ozone values by transport. This effect becomes even more evident when employing an ozone origin diagnostic, as presented for E39CA in Garny et al. (2011) (see their Fig. 10).

The strong chemically-induced trends in ozone occur close to the tropopause, which moves upward from the 1960s to the 2040s. One might suspect that the trend in the tropopause height is in some way responsible for the ozone trends. We calculated the trends in ozone profiles in vertical coordinates relative to the tropopause height (not shown). The slight reduction in positive trends in ozone at and above the tropopause in both the $\mathrm{NH}$ and $\mathrm{SH}$ seen in Fig. 8 vanishes when calculating the trends relative to the tropopause, as can be expected from an upward shift of the tropopause. Otherwise, the results are unaffected, and we can conclude that the chemically-induced positive ozone trend around $250 \mathrm{hPa}$ is not the result of a vertical shift of the tropospheric regime.

Below $500 \mathrm{hPa}$ in the $\mathrm{NH}$ and around $300 \mathrm{hPa}$ in the $\mathrm{SH}$, the transport term becomes positive, reinforcing the positive ozone trend. This suggests that ozone transport into this region dominates transport out of this region, resulting from the stronger local production of ozone. It is most likely that it is ozone produced above these levels, and transported downward, possibly together with horizontal transport, that leads to the overall positive contribution to ozone changes. Close to the surface, particularly in the $\mathrm{NH}$, the increase in ozone due to chemistry again dominates. Again, transport changes offset the chemically-induced positive trend.

The hemispheric differences are highlighted in the lowermost panel in Fig. 8, showing that ozone trends are stronger in the $\mathrm{NH}$ compared to the $\mathrm{SH}$, in particular in the upper troposphere. The stronger increase in ozone in the $\mathrm{NH}$ can be attributed to stronger chemically-induced ozone trends. The contribution from changes in transport largely offsets the contribution from changes in chemistry, but does not itself lead to asymmetric ozone trends in the LMSTR and troposphere. The induced asymmetry by chemistry is due to ozone production by $\mathrm{NO}_{\mathrm{x}}$, which increases more strongly in the $\mathrm{NH}$, as will be shown in Sect. 6.1.

\subsection{Lower stratosphere}

Causes of ozone trends in the LSTR are investigated in more detail using the NIWA-SOCOL model. The ozone trends in this model behave similarly to the multi-model mean in the LSTR (see Figs. 4 and 6). E39CA, on the other hand, does not simulate the earlier return of NH ozone in the LSTR to 1980 levels, and the ozone trend profile is very different to most other models.

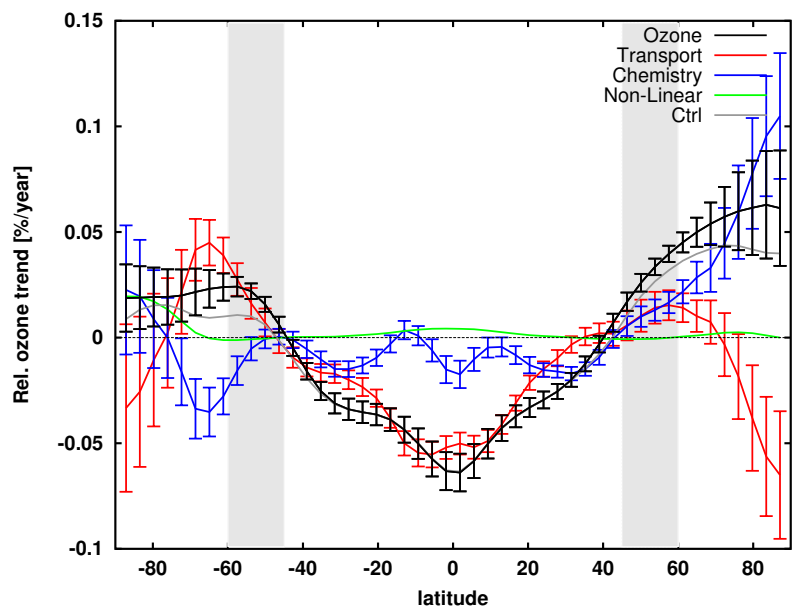

Fig. 9. Trend regression coefficients as a function of latitude for NIWA-SOCOL of lower stratospheric partial column ozone (black), transport-induced ozone trends (red) and chemically-induced ozone trends (blue). The green line line is the nonlinear contribution to ozone trends, and the grey line is the control line (sum of chemistry, transport and nonlinear term). Light grey bars indicate the mid-latitude averaging region used in this study.

First, the latitudinal structure of trends in the LSTR partial ozone column from NIWA-SOCOL is shown in Fig. 9. Ozone trends are negative in the tropics, and positive at middle to high latitudes. Extratropical ozone trends are slightly stronger in the $\mathrm{NH}$ compared to the $\mathrm{SH}$, consistent with earlier ozone return dates in the NH. The attribution of ozone trends shows that transport-induced changes lead to a decrease in ozone in the tropics and increases in the extratropics. The transport-induced trends change sign at about $45^{\circ} \mathrm{N} / \mathrm{S}$, motivating the choice of that latitude as equatorward boundary for our definition of midlatitudes. The transport-induced ozone trends are consistent with an enhanced strength of the BDC (see Fig. 6). However, the stronger northern mid-latitude trends compared to southern mid-latitudes in NIWA-SOCOL cannot be explained by differences in transport. Rather, transport changes induce stronger positive ozone trends in the southern mid-latitudes compared to the northern mid-latitudes. The transport-induced trends in the SH are, partially, compensated by strong negative trends induced by chemistry changes.

To elucidate this point further, profiles of mid-latitude (45$60^{\circ} \mathrm{N} / \mathrm{S}$ ) ozone trends, attributed to changes in chemistry and transport within NIWA-SOCOL, are shown in Fig. 10. Ozone trends at $100 \mathrm{hPa}$ are positive in both hemispheres, decreasing with height up to $70 \mathrm{hPa}$, where the trend in the $\mathrm{SH}$ is slightly negative. Above $70 \mathrm{hPa}$ trends increase with height and are positive throughout the LSTR.

Ozone trends induced by transport are positive at all levels in the LSTR in both hemispheres, but maximize at $100 \mathrm{hPa}$ and are close to zero above $20 \mathrm{hPa}$. Ozone trends due to 

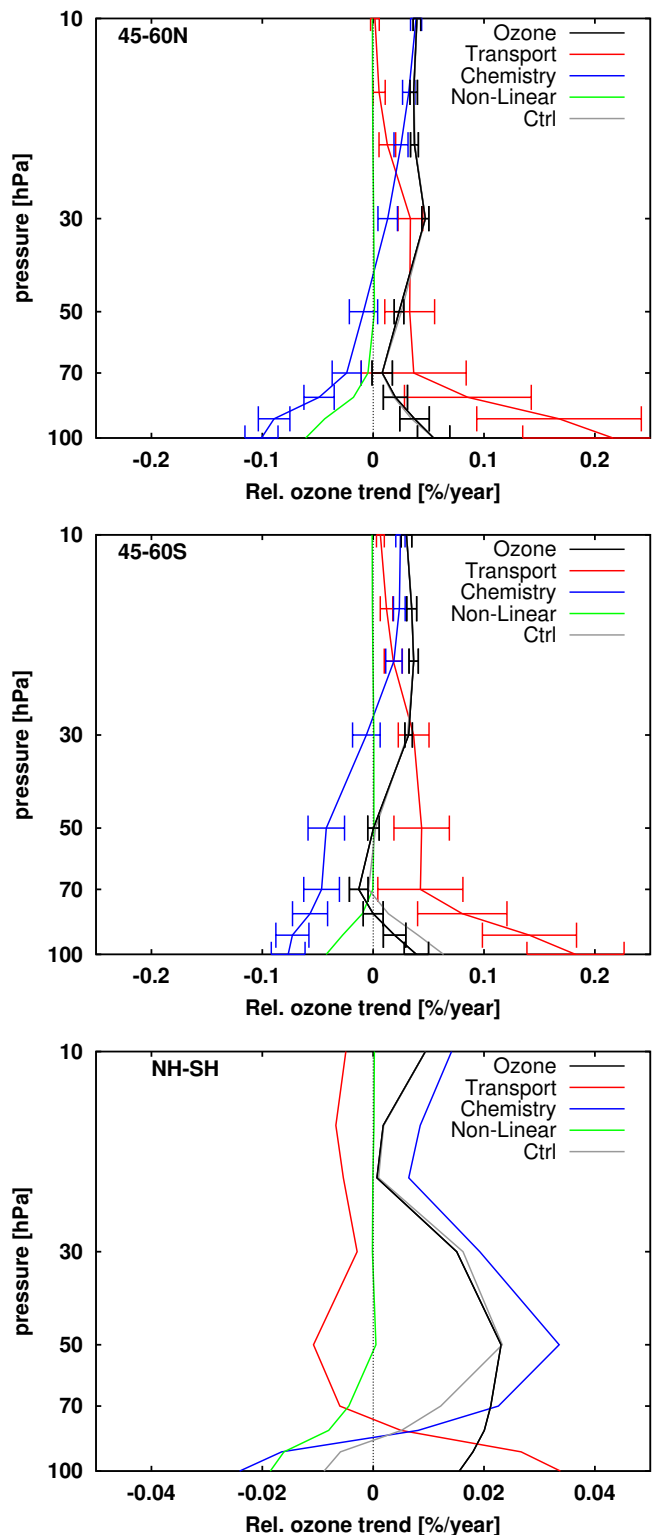

Fig. 10. As in Fig. 8 but for lower stratospheric ozone trends in NIWA-SOCOL.

changes in chemistry are negative to around 40 to $30 \mathrm{hPa}$, and dominate the positive ozone trend above $20 \mathrm{hPa}$ in both hemispheres. The positive trend induced by transport is again consistent with a strengthened BDC, and the decrease of the effect with height is expected from the decreasing lifetime of ozone with height.

The hemispheric differences in ozone trends, as shown in the lower panel of Fig. 10, are positive throughout the LSTR, maximizing at $50 \mathrm{hPa}$. Changes in transport are the main cause of relatively stronger $\mathrm{NH}$ trends below $80 \mathrm{hPa}$, and are slightly negative below. The hemispheric differences in transport-induced trends appear contradictory to the hemispheric differences in trends in the residual mass fluxes (see
Fig. 6). However, transport of ozone is determined not only by the strength of the mass fluxes, but also by the available background ozone, which is influenced by chemistry. The negative chemically-induced ozone trends below 30 to $40 \mathrm{hPa}$ lead to less ozone being available for transport. Thus, the stronger negative chemically-induced trend in the $\mathrm{SH}$ than in the $\mathrm{NH}$ above $80 \mathrm{hPa}$ might be the cause for the stronger positive transport-induced trend. Below $50 \mathrm{hPa}$, the sum of the attribution terms deviates from the actual ozone trend differences, making the attribution less reliable. As discussed in Sect. 7, the dominant role of chemically-induced changes is robust against the uncertainties introduced by the method.

Integrated over the lower stratospheric column, transportinduced trends are positive in both hemispheres, but stronger in the SH. Chemistry-induced trends, on the other hand, are positive in the $\mathrm{NH}$ but negative in the $\mathrm{SH}$, and these large hemispheric differences lead to the overall stronger trend in the NH (see Fig. 9). These different trends are then reflected in the return dates, as summarized in Fig. 16. The causes for asymmetric ozone trends induced by chemistry in the lower stratosphere are investigated in Sect. 6.2.

\section{Hemispheric differences in chemically-induced ozone trends}

\subsection{Lowermost stratosphere and troposphere: enhancement in production by $\mathrm{NO}_{\mathrm{x}}$}

In the LMSTR and upper troposphere, strong positive trends in ozone are induced by changes in chemistry. Chemicallyinduced trends are stronger in the NH than in the SH. The contributions of individual reaction cycles to the chemicallyinduced increase in ozone are averaged between 300 and $250 \mathrm{hPa}$ and are shown in Fig. 11. The primary contributor to ozone trends in this region, and the primary cause of hemispheric differences in ozone trends, is an increase in the production of ozone by $\mathrm{NO}_{\mathrm{x}}$, in particular via the $\mathrm{HO}_{2}+\mathrm{NO}$ cycle (the bars labeled "PHN" in Fig. 11), which is significantly stronger in the $\mathrm{NH}$ than in the $\mathrm{SH} . \mathrm{NO}_{\mathrm{x}}$ concentrations increase in the troposphere due to stronger emissions, and the increase is stronger in the $\mathrm{NH}$, affecting tropospheric ozone (Lelieveld and Dentener, 2000). Comparisons of $\mathrm{NO}_{\mathrm{x}}$ trends in the troposphere and LMSTR between different CCMs showed clear discrepancies between individual models (not shown), most likely as a result of differences in the prescribed emissions (or concentrations) and differences in the way that tropospheric chemistry is simulated in the CCMs. In $\mathrm{E} 39 \mathrm{CA}, \mathrm{NO}_{\mathrm{x}}$ trends $\sim 200 \mathrm{hPa}$ are stronger compared to other models. Therefore, the effect of enhanced production from the $\mathrm{NO}_{\mathrm{x}}$ cycles on ozone trends, as shown here, might be overestimated. Consistently, ozone trends below $150 \mathrm{hPa}$ are stronger in E39CA compared to the multi-model mean (see Fig. 4). However, four of the models show tropospheric 

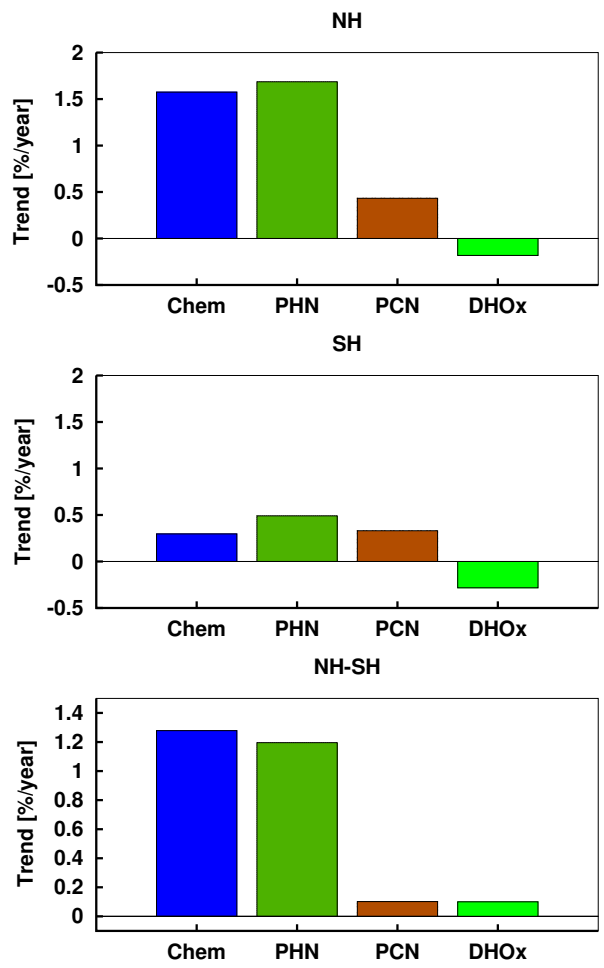

Fig. 11. Contributions to the chemically-induced ozone trends (blue bars) in the NH (top) and SH (middle) mid-latitudes, and the hemispheric difference (bottom), integrated between 250 and $300 \mathrm{hPa}$ in E39CA. Reaction cycles are the production via $\mathrm{HO}_{2}+\mathrm{NO}$ ("PHN") and $\mathrm{CH}_{3} \mathrm{O}_{2}+\mathrm{NO}(\mathrm{PCN})$, and the $\mathrm{HO}_{\mathrm{x}}$ destruction cycle. The Chapman production cycles and the $\mathrm{NO}_{\mathrm{x}}$ and $\mathrm{ClO}_{\mathrm{x}}$ destruction cycles are omitted since their contributions are close to zero.

ozone trends close to zero (most likely models that neglect tropospheric chemistry), thus biasing the multi-model mean to lower values. In general, tropospheric chemistry is often treated in a simplified manner in CCMs, introducing uncertainty on the results shown here, as will be further discussed in Sect. 7.

\subsection{Lower stratospheric chemistry}

Changes in chemistry were shown to be the primary contributor to hemispheric differences in LSTR ozone trends. The chemically-induced trend profiles from Fig. 10 are further divided into individual reaction cycles in Fig. 12.

Below 30 to $40 \mathrm{hPa}$, ozone trends induced by changes in chemistry are negative, caused primarily by changes in rates of ozone destruction by the $\mathrm{HO}_{x}$ cycles. The destruction rates of the $\mathrm{HO}_{\mathrm{x}}$ cycle are affected by increasing $\mathrm{CH}_{4}$ concentrations, with $\mathrm{CH}_{4}$ being the primary source of stratospheric $\mathrm{HO}_{\mathrm{x}}$ (Wuebbles and Hayhoe, 2002). Stratospheric water vapor is projected to increase in a future climate (Gettelman et al., 2010), leading to enhanced ozone destruction (Stenke and Grewe, 2005), consistent with the negative ozone trends induced by $\mathrm{HO}_{\mathrm{x}}$ in Fig. 12 .
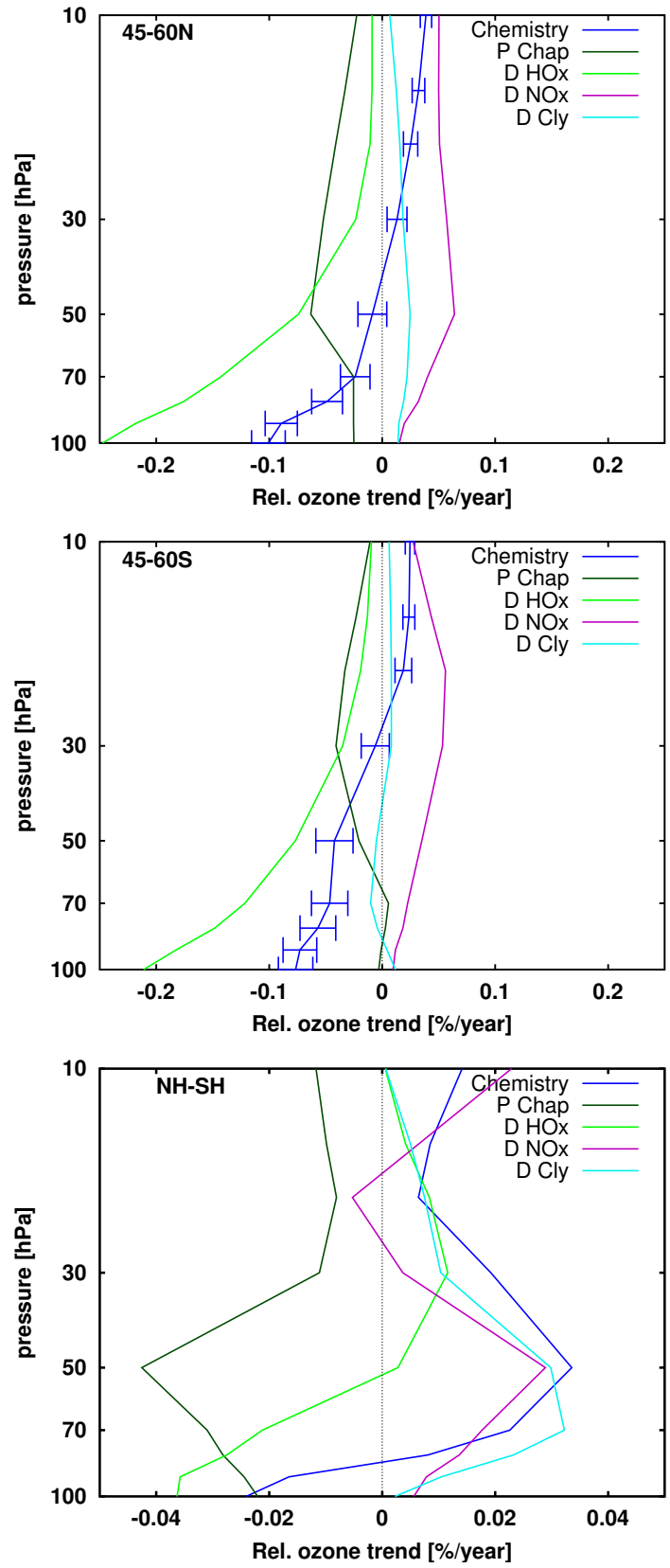

Fig. 12. As in Fig. 10 but showing the contributions of different reaction cycles (see legend) to the total chemically-induced ozone trend (blue).

Changes in the rates of ozone destruction by the $\mathrm{NO}_{\mathrm{x}}$ cycles cause an increase in ozone throughout the lower stratosphere, dominating the total chemically-induced ozone trends above around $40 \mathrm{hPa}$. Changes in rates of ozone destruction by the $\mathrm{NO}_{\mathrm{x}}$ cycles were analyzed in detail, based on the same NIWA-SOCOL simulation as used here by Revell et al. (2012b). They showed that the decrease in ozone destruction by $\mathrm{NO}_{\mathrm{x}}$, despite an increase in $\mathrm{N}_{2} \mathrm{O}$, is caused by a decrease in the ratio of $\mathrm{NO}_{\mathrm{x}}$ to $\mathrm{N}_{2} \mathrm{O}$ and a reduction 


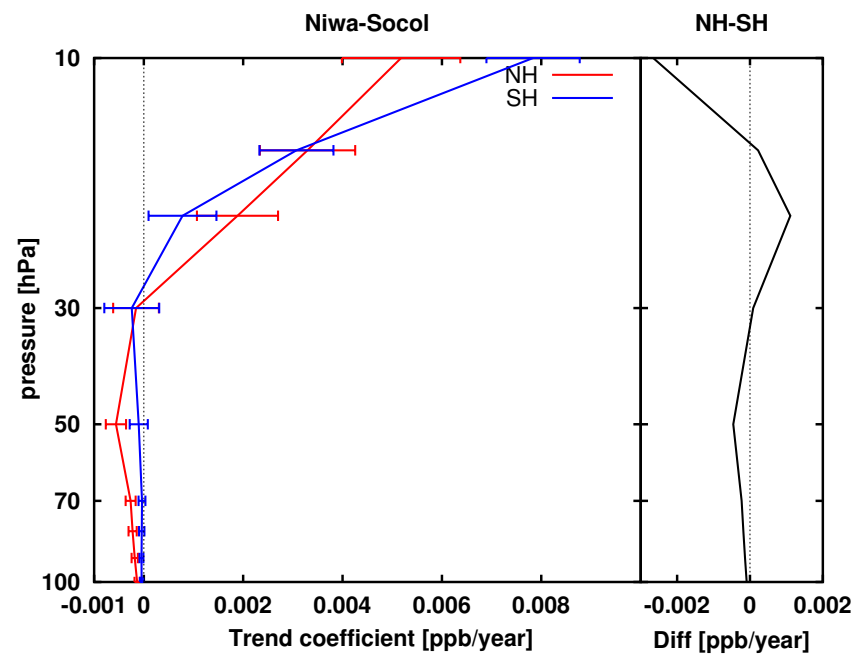

Fig. 13. Trend coefficients from NIWA-SOCOL of $\mathrm{NO}_{\mathrm{x}}$ averaged over 45 to $60^{\circ} \mathrm{N}$ (red) and 45 to $60^{\circ} \mathrm{S}$ (blue) as a function of height. The error bars are the one $\sigma$ uncertainties in the fit coefficients. The right panel shows the $\mathrm{NH}-\mathrm{SH}$ difference.

in the available atomic oxygen, both in turn largely due to GHG-induced stratospheric cooling.

The largest hemispheric differences in chemically-induced ozone trends occur at $50 \mathrm{hPa}$, and are primarily due to ozone destruction by the (i) $\mathrm{NO}_{\mathrm{x}}$ cycles and (ii) $\mathrm{Cl}_{\mathrm{y}}$ cycles (see lower panel in Fig. 12). Ozone destruction by the $\mathrm{HO}_{\mathrm{x}} \mathrm{cy}-$ cles leads to stronger negative ozone trends around $100 \mathrm{hPa}$ in the $\mathrm{NH}$. Overall, $\mathrm{HO}_{\mathrm{x}}$ chemistry counteracts the effects of the $\mathrm{NO}_{\mathrm{x}}$ and $\mathrm{Cl}_{\mathrm{y}}$ cycles in the lower stratosphere (see Fig. 16) and plays a minor role for hemispheric asymmetries in ozone trends. The $\mathrm{HO}_{\mathrm{x}}$-induced trends are thus not further discussed here. The increase in ozone caused by reduced ozone destruction by $\mathrm{NO}_{\mathrm{x}}$ is stronger in the $\mathrm{NH}$ compared to the SH. The hemispheric differences in ozone trends due to changes in the $\mathrm{Cl}_{\mathrm{y}}$ destruction cycles maximize at $70 \mathrm{hPa}$. While the changes caused by the $\mathrm{Cl}_{\mathrm{y}}$ destruction cycles are slightly positive in the $\mathrm{NH}$, they are negative in the $\mathrm{SH}$ at $70 \mathrm{hPa}$. The drivers of the trends in the destruction rates of the $\mathrm{Cl}_{\mathrm{y}}$ and $\mathrm{NO}_{\mathrm{x}}$ cycles are investigated below.

\subsubsection{Changes in $\mathrm{NO}_{\mathrm{x}}$ destruction rates}

As discussed above, Revell et al. (2012b) showed that the effectiveness of $\mathrm{N}_{2} \mathrm{O}$ in depleting ozone is determined by $\mathrm{NO}_{\mathrm{x}}$ concentrations and by the availability in atomic oxygen. The former is strongly influenced by cooling of the stratosphere (Rosenfield and Douglass, 1998) and by changes in the strength of the BDC (Cook and Roscoe, 2012).

In Fig. 13, the vertical profile of linear trends in midlatitude $\mathrm{NO}_{\mathrm{x}}$ over the period 1960 to 2049 are shown, calculated in the same manner as the ozone trends, i.e., using a regression model taking an offset, $\mathrm{Cl}_{\mathrm{y}}$ and a linear trend into account. Below $30 \mathrm{hPa}, \mathrm{NO}_{\mathrm{x}}$ mixing ratios decrease slightly in the $\mathrm{NH}$, whereas trends in the $\mathrm{SH}$ are close to zero. Above $30 \mathrm{hPa}$, trends are positive in both hemispheres and increase with height. Despite this increase in $\mathrm{NO}_{\mathrm{x}}$ in both hemispheres above $30 \mathrm{hPa}$, ozone loss by the $\mathrm{NO}_{\mathrm{x}}$ cycle decreases in this region. As explained by Revell et al. (2012b), this results from a decrease in the availability of atomic oxygen, which in turn is due to decreasing temperatures and to competition with other ozone destruction cycles, in particular the $\mathrm{HO}_{\mathrm{x}}$ cycles.

The difference in the $\mathrm{NO}_{\mathrm{x}}$ trends between the hemispheres, shown in the right panel, closely matches the difference in the $\mathrm{NO}_{\mathrm{x}}$-destruction-induced ozone trends shown in Fig. 12; the stronger increase in $\mathrm{NH}$ ozone compared to the $\mathrm{SH}$ at $50 \mathrm{hPa}$ is consistent with a slight decrease of $\mathrm{NO}_{\mathrm{x}}$ in the $\mathrm{NH}$ and close to zero trend in $\mathrm{NO}_{\mathrm{x}}$ in the $\mathrm{SH}$. At $20 \mathrm{hPa}$, the sign of the hemispheric difference in $\mathrm{NO}_{\mathrm{x}}$ trends is reversed (but uncertainties are large and trends are not statistically different), which is reflected in a slightly negative hemispheric difference in $\mathrm{NO}_{\mathrm{x}}$-destruction-induced ozone trends (as shown in Fig. 12). At $10 \mathrm{hPa}$ the $\mathrm{NO}_{\mathrm{x}}$ trend in the $\mathrm{SH}$ is significantly stronger compared to the $\mathrm{NH}$. This hemispheric difference in $\mathrm{NO}_{\mathrm{x}}$ trends increases further up to $5 \mathrm{hPa}$ (not shown). The stronger positive ozone trend, due to reduced $\mathrm{NO}_{\mathrm{x}}$-induced ozone destruction changes in the $\mathrm{NH}$ compared to the $\mathrm{SH}$ at $10 \mathrm{hPa}$ (see Fig. 12), can again be explained by the asymmetric $\mathrm{NO}_{\mathrm{x}}$ trends. Overall, the hemispheric differences in the trends in ozone destruction rates by the $\mathrm{NO}_{\mathrm{x}}$ cycle are consistent with hemispheric differences in $\mathrm{NO}_{\mathrm{x}}$ trends.

\subsubsection{Changes in $\mathrm{Cl}_{\mathrm{y}}$ destruction rates}

In the LSTR, the efficiency of homogenous $\mathrm{Cl}_{\mathrm{y}}$ ozone destruction cycles is expected to decrease with decreasing temperatures (Rosenfield et al., 2002). As shown in Fig. 12, ozone trends due to changes in destruction rates by the $\mathrm{Cl}_{\mathrm{y}}$ cycles are slightly positive throughout the lower stratosphere in the $\mathrm{NH}$, consistent with decreasing temperatures. In the $\mathrm{SH}$, on the other hand, a reduction in ozone resulting from an increase in the $\mathrm{Cl}_{\mathrm{y}}$ destruction rates is found at $70 \mathrm{hPa}$.

The increase in ozone destruction rates cannot be due to changes in the abundance of $\mathrm{Cl}_{\mathrm{y}}$, since any changes in ozone congruent with $\mathrm{Cl}_{\mathrm{y}}$ changes are included in the $\mathrm{Cl}_{\mathrm{y}}$ regression coefficient. Therefore, the trend in ozone destruction rates must be caused by changes in the efficiency of a given amount of $\mathrm{Cl}_{\mathrm{y}}$ to destroy ozone. The efficiency is determined by temperature, with lower temperatures slowing homogeneous reaction cycles. However, at very low temperatures, as those occurring in the Antarctic vortex, ozone can be depleted efficiently by heterogeneous chemistry. Hence, any expansion in space or time of the region where the conditions for heterogeneous chemistry occur can cause an increase in the efficiency of the $\mathrm{Cl}_{\mathrm{y}}$ ozone destruction cycles.

Trends in the rates of ozone destruction rates by the $\mathrm{Cl}_{\mathrm{y}}$ cycles in southern mid-latitudes at $70 \mathrm{hPa}$ are shown as a 


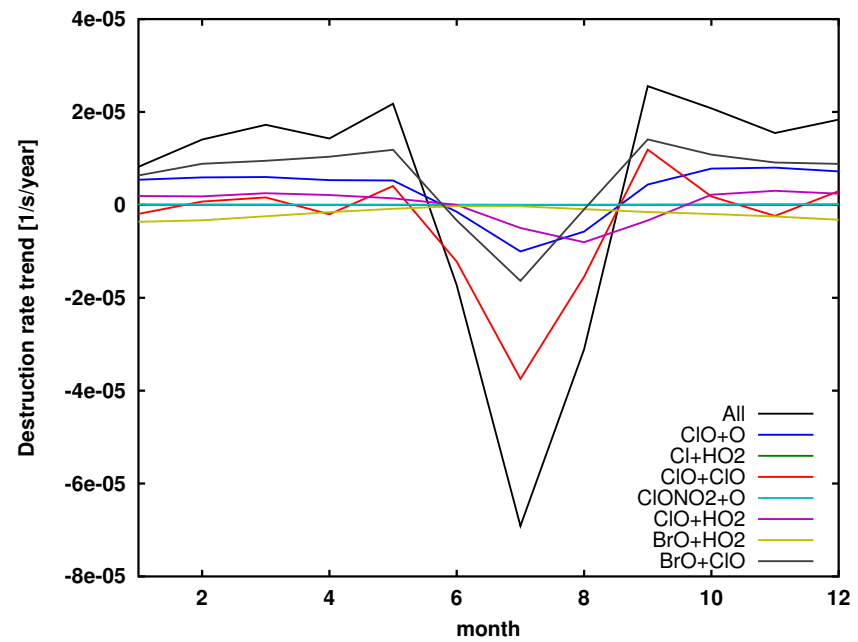

Fig. 14. Trend coefficients from NIWA-SOCOL of the destruction rates by the $\mathrm{Cl}_{\mathrm{y}}$ cycles averaged over 45 to $60^{\circ} \mathrm{S}$ at $70 \mathrm{hPa}$ of the sum of all reaction cycles (black line) and individual cycles (in color, as indicated by the legend).

function of month in Fig. 14. Destruction rates increase (i.e., larger negative values) in midwinter, and the trend maximizes in July. When disaggregating the destruction rates into individual reaction cycles, it can be seen that the largest contributor to the destruction rate increase in midwinter is the ClO-dimer reaction cycle. Therefore, it is mostly heterogeneous chemistry that is responsible for the increased efficiency of ozone destruction. In midwinter, the polar night prohibits heterogeneous ozone depletion south of $66.5^{\circ} \mathrm{S}$ for varying periods since sunlight is required for the photochemical reactions. Figure 15 shows the trend in temperatures over the southern middle to high latitudes at $70 \mathrm{hPa}$ in July, where the increase in heterogeneous ozone depletion maximizes. Temperature trends are negative over the polar region and maximize $\sim 60^{\circ} \mathrm{S}$ and $150^{\circ} \mathrm{W}$. The pattern is suggestive of an intensification and shift of the polar vortex center away from the pole. Through this process, polar vortex air with low temperatures reaches latitudes equatorward of $60^{\circ} \mathrm{S}$, where sunlight is available in midwinter, allowing for heterogeneous ozone depletion. This process can explain the negative trend in ozone at southern mid-latitudes at $70 \mathrm{hPa}$ in NIWA-SOCOL.

\section{Discussion}

The implications of and uncertainties in the results presented in the last sections will be discussed in the following. The results obtained with the attribution analysis (Sects. 5 and 6) are subject to two kinds of uncertainties: (1) uncertainties in the attribution method itself, and (2) uncertainties in the model used for the attribution analysis. The latter refers to the question of whether we can expect the processes identi-

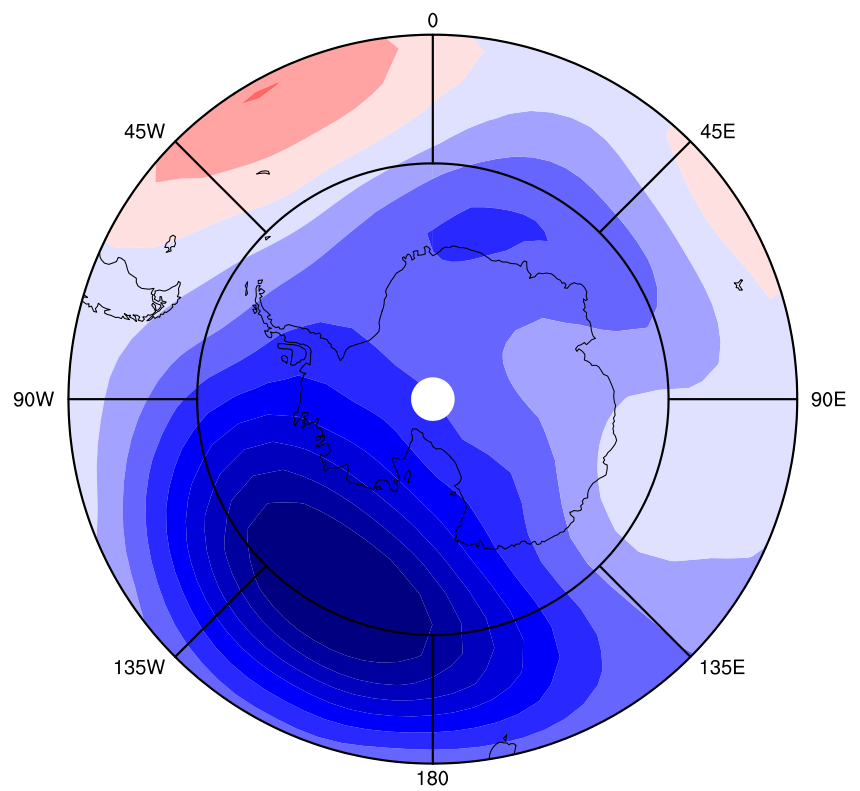

Temperature trend [K/year]

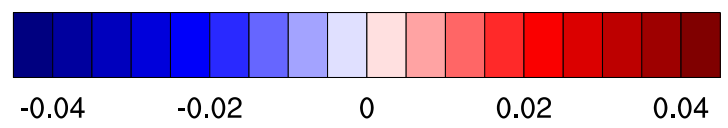

Fig. 15. Trends (1960 to 2049) in temperatures at $70 \mathrm{hPa}$ in July from NIWA-SOCOL. The outer margin lies at $45^{\circ} \mathrm{S}$, and $60^{\circ} \mathrm{S}$ is marked as inner black circle.

fied in E39CA and NIWA-SOCOL to be of similar importance in other CCMs. To answer this question, the attribution analysis would have to be applied to other models as well, which requires knowledge of the chemical loss and production rates. However, the comparison of NIWA-SOCOL and E39CA to the ensemble analysis of CCMs presented in the first half of the paper and to earlier studies allows us some estimations.

\subsection{What is the role of transport for hemispheric asymmetric ozone trends?}

Both the analysis of the relation of hemispheric differences in mid-latitude ozone return dates to asymmetric trends in the strength of the BDC and the attribution analysis to chemical and transport changes showed evidence that changes in transport of ozone plays a smaller role in explaining hemispherically asymmetric return dates than previously thought.

In the lower stratosphere, no significant correlation of ozone return date differences to asymmetric trends in the BDC strength is found across a set of twelve models. The attribution of ozone trends to transport and chemistry changes applied to NIWA-SOCOL showed that transport changes induce stronger positive ozone trends in the $\mathrm{NH}$ than $\mathrm{SH}$ at levels around $100 \mathrm{hPa}$. However, above $80 \mathrm{hPa}$, transportinduced ozone trends are stronger in the $\mathrm{SH}$ than in the $\mathrm{NH}$. 


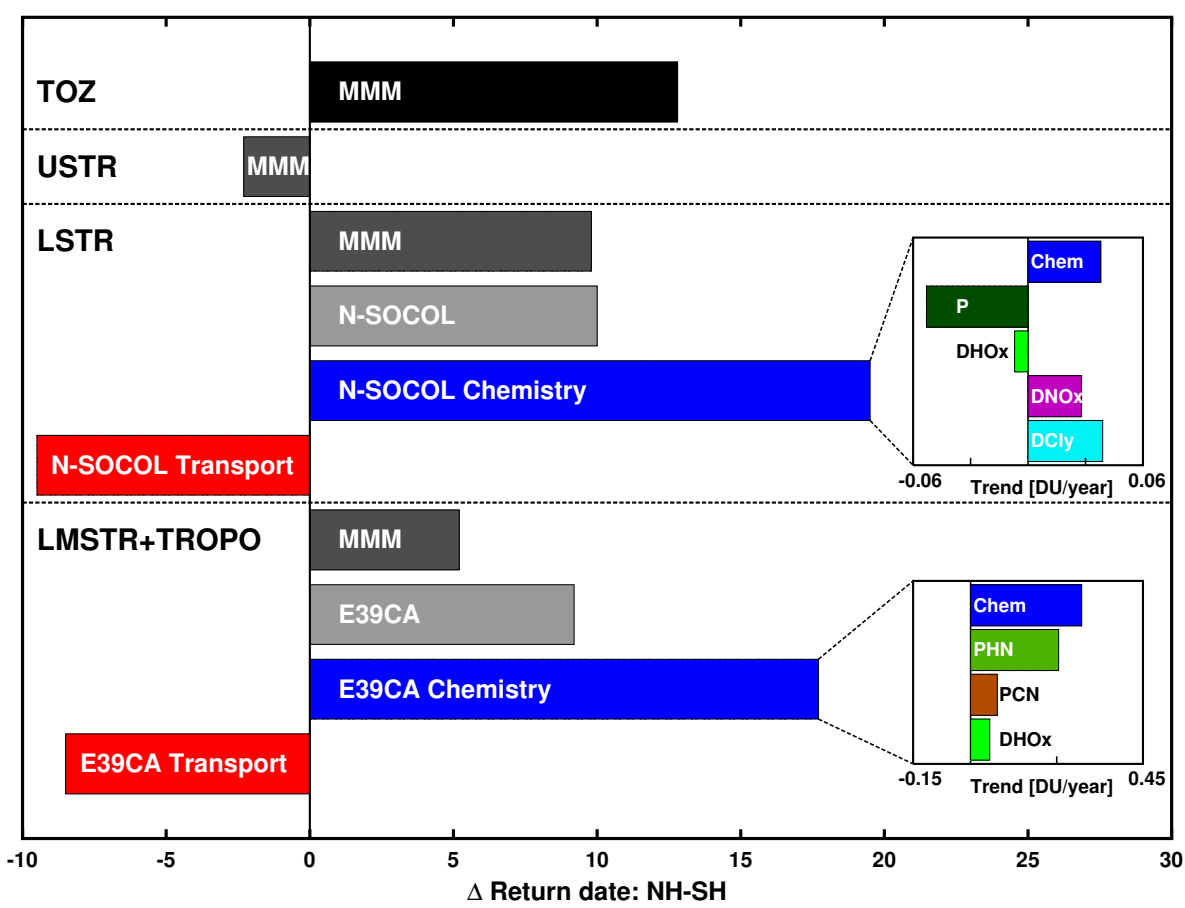

Fig. 16. Summary of the results: hemispheric differences in mid-latitude return dates to 1980 values are about $13 \mathrm{yr}$ in the multi-model mean (MMM) for TOZ. Upper stratospheric ozone contributed negatively to this difference, while return dates of lower stratospheric ozone (100 to $10 \mathrm{hPa}$ ) alone have a hemispheric difference of about $10 \mathrm{yr}$, and ozone below $100 \mathrm{hPa}$ contributes another $5 \mathrm{yr}$. In the LSTR, in NIWASOCOL changes in chemistry only would lead to an earlier return in the $\mathrm{NH}$ of close to $20 \mathrm{yr}$, and changes in transport of ozone offset the chemical effects. Attribution of chemically-induced trends in the LSTR show that the earlier return of NH ozone is due to changes in the $\mathrm{NO}_{\mathrm{x}}$ and $\mathrm{Cl}_{\mathrm{y}}$ cycles. In the lowermost stratosphere and troposphere, hemispheric differences modeled in E39CA, somewhat above-average, are attributed to changes in chemistry, and transport offsets the chemically-induced changes. Enhanced production of ozone in the NH by the $\mathrm{NO}_{\mathrm{x}}$ cycles is found to account for the stronger positive trend there.

Figure 16 shows how the lower stratospheric ozone trends translate to return dates. The positive transport-induced trends shift return dates forward in both hemispheres, but more so in the SH. The positive chemically-induced trend in the NH shifts the return date even further forward, while the chemically-induced trend is negative in the $\mathrm{SH}$, leading to a later return date here. Thus, overall, chemically-induced trends are the major cause of the hemispheric differences in ozone return dates.

However, to obtain meaningful results with the attribution method, the changes in annual mean ozone tendencies needs to be small (i.e., the "imbalance" term negligible), so that the chemically- and transport-induced changes together with the nonlinear contribution equal the total change in ozone. As seen in Fig. 10, this is not the case below $50 \mathrm{hPa}$ in the Southern Hemisphere, resulting in a discrepancy also in the hemispheric difference. These are the levels where transportinduced trends are of major importance; thus could we underestimate transport effects due to problems with the method in exactly the regions where transport seems to matter most? Let us assume that the difference between the estimated and actual ozone changes (i.e., the grey and black solid line in Fig. 10) would be entirely due to transport changes. Thus, we increase the hemispheric differences in transport-induced trends so that the estimated and actual ozone trends match. Then, the overall effect of transport changes on hemispheric differences in ozone trends in the lower stratospheric column would be slightly positive instead of negative. However, chemically-induced asymmetry in return dates in the lower stratospheric column would still dominate over the transportinduced asymmetry by a factor of 10 . Thus, the conclusion that chemistry is the dominant factor in driving hemispheric asymmetries in lower stratospheric ozone trends is insensitive to the uncertainties in the attribution method.

Concerning uncertainties stemming from the choice of the model, NIWA-SOCOL simulates increases in the strength of the mass fluxes that are above average (Fig. 6). The hemispheric differences in the $70 \mathrm{hPa}$ mass fluxes are slightly larger compared to most models (Fig. 7). Thus, if transport were to play an important role in driving asymmetric ozone trends, it should be apparent in the NIWA-SOCOL model.

In general, current CCMs are run with a rather coarse resolution due to restrictions in computational costs. Transport might be dependent on the model resolution and the chosen advection scheme, and in particular the role of smaller-scaled transport processes in the tropopause region might not be 
captured properly. How strongly transport of ozone is scaledependent, and whether this has any implications for the simulated trends, is an open question future studies will have to address.

In the lowermost stratosphere, we found a weak correlation between the hemispheric differences in the BDC changes at $100 \mathrm{hPa}$ and the differences in return dates for the ensemble of twelve CCMs. A closer investigation with E39CA showed that the positive trends in this region are in large part caused by chemically-induced changes, which are stronger in the $\mathrm{NH}$ and thus introduces hemispheric differences. The attribution method works reasonably well in this region for E39CA, as seen from the approximate agreement of the ozone changes and control line (black dashed) in Fig. 8. The model E39CA simulates stronger than average strengthening of the downward mass flux at $100 \mathrm{hPa}$ (Fig. 6), but hemispheric differences here are small (Fig. 7). A group of four models simulate stronger hemispheric differences in the mass flux trends and larger asymmetries in the return dates. Thus, for this group of models, transport changes might play a larger role. Another group of five models simulates two to five years earlier return dates of LMSTR ozone in the NH, but stronger mass flux increases in the $\mathrm{SH}$ than to the NH. For this group of models, the correlation between return date difference and asymmetric circulation changes apparently breaks down. Thus, it appears likely that at least in this group of models, chemically-induced changes play the leading role in introducing the hemispheric differences.

Overall the results suggest that the hemispheric differences in ozone trends, and thus return dates in the lowermost stratosphere are caused by a combination of (i) enhanced ozone production by increasing $\mathrm{NO}_{\mathrm{x}}$ concentrations, which is stronger in the $\mathrm{NH}$, and (ii) hemispheric different transport changes due to the hemispheric asymmetric BDC trends. The relative importance of the mechanisms probably varies from model to model.

\subsection{What is the relevance of the identified chemical processes?}

\subsubsection{Lowermost stratosphere and troposphere: $\mathrm{NO}_{\mathrm{x}}$-related production}

In the lowermost stratosphere and upper troposphere, analysis of the E39CA model reveals an important contribution to positive ozone trends from ozone production by the $\mathrm{NO}_{\mathrm{x}}$ production cycles. Due to stronger increases in $\mathrm{NO}_{\mathrm{x}}$ concentrations in the $\mathrm{NH}$, the production increase is larger there compared to the $\mathrm{SH}$, and thus leads to asymmetric ozone trends. Even though the absolute amount of $\mathrm{NO}_{\mathrm{x}}$ seems to be simulated well in E39CA (as indicated by a brief comparison to a tropospheric chemistry model and to observations, not shown), the trends are larger compared to other CCMs. Thus, the effect of $\mathrm{NO}_{\mathrm{x}}$-related ozone production might be less relevant in other CCMs. In addition, despite E39CA having been used to examine variability in tropospheric ozone, the model incorporates only background tropospheric chemistry, which limits the capabilities to accurately simulate trends (Grewe, 2007). The increase in the tropospheric ozone burden from 2000 to 2030 of around $10 \%$ in E39CA compares reasonably well with the estimates of an ensemble of models focused on tropospheric chemistry of 6 to $15 \%$, depending on the scenario, as given by Stevenson et al. (2006). However, more recent results indicate that tropospheric ozone is more likely to decrease until 2030 under a moderate emission scenario (Young et al., 2013). Observations also indicate that the positive trends, in particular in $\mathrm{NH}$ tropospheric ozone from 1970 to about 1990, flattened or even reversed over the last 10-15 yr (Oltmans et al., 2013). Thus, the positive ozone trends in the troposphere simulated by most CCMs used in this study over the period 1960 to 2049 might be unrealistic. Tropospheric ozone trends are found to be strongly coupled to trends in $\mathrm{NO}_{\mathrm{x}}$ also in models with more sophisticated tropospheric chemistry schemes (Young et al., 2013). It remains unclear how much tropospheric ozone trends in CCMs are affected by the prescribed $\mathrm{NO}_{\mathrm{x}}$ emissions (or concentrations), or by simplified tropospheric chemistry schemes. Projections with CCMs with improved tropospheric chemistry schemes will need to be analyzed to conclude with more certainty on the role tropospheric ozone trends play for return dates in total column ozone.

\subsubsection{Lower stratosphere: $\mathrm{NO}_{\mathrm{x}}$ destruction cycles}

The hemispheric differences in the decrease of ozone destruction by the $\mathrm{NO}_{\mathrm{x}}$ cycles are found to be controlled by hemispheric differences in the trends in $\mathrm{NO}_{\mathrm{x}}$ concentrations. The detailed analysis of the causes for the hemispheric differences in $\mathrm{NO}_{\mathrm{x}}$ trends are beyond the scope of this study. From previous studies, it is known that trends in stratospheric $\mathrm{NO}_{\mathrm{x}}$ concentrations are influenced by the speed of the BDC (Plummer et al., 2010; Cook and Roscoe, 2012). Thus, one possible explanation of the hemispheric differences in $\mathrm{NO}_{\mathrm{x}}$ trends could be a feedback of changes in the circulation on the efficiency of the production of $\mathrm{NO}_{\mathrm{x}}$. As shown by Cook and Roscoe (2012) in a simplified model approach, an increase in the $\mathrm{BDC}$ causes a decrease in the formation of $\mathrm{NO}_{\mathrm{x}}$ (since the time available for photolysis decreases, and this effect dominates over the enhanced influx of the tropospheric source gas $\mathrm{N}_{2} \mathrm{O}$ ). Climatologically, the BDC is stronger in the $\mathrm{NH}$ compared to the $\mathrm{SH}$, and in agreement with the work of Cook and Roscoe (2012), climatological $\mathrm{NO}_{\mathrm{x}}$ concentrations in NIWA-SOCOL are higher in the SH than in the $\mathrm{NH}$ (not shown). A stronger increase in the strength of the $\mathrm{BDC}$ in the middle stratosphere of the $\mathrm{NH}$ could thus explain weaker positive $\mathrm{NO}_{\mathrm{x}}$ trends in the $\mathrm{NH}$ compared to the $\mathrm{SH}$.

Compared to other models, trends in $\mathrm{NO}_{\mathrm{x}}$ concentrations at $10 \mathrm{hPa}$ in NIWA-SOCOL are of similar magnitude. In addition, most models show a stronger $\mathrm{NO}_{\mathrm{x}}$ trend in the $\mathrm{SH}$ 
than in the $\mathrm{NH}$ (not shown), indicating that the hemispheric asymmetric changes in $\mathrm{NO}_{\mathrm{x}}$ concentrations can be a relevant factor in determining the hemispheric different ozone trends and thus return dates.

As opposed to most other models, E39CA simulates a slightly earlier return of lower stratospheric ozone in the SH than in the NH (see Fig. 7), and ozone trends are negative above $30 \mathrm{hPa}$ in contrast to the remaining group of CCMs analyzed here (see Fig. 4). The attribution analysis in the lower stratosphere for E39CA (not shown) reveals that the chemically-induced ozone trend, and in particular the $\mathrm{NO}_{\mathrm{x}}$ destruction cycles, are responsible for the decrease in ozone above $30 \mathrm{hPa}$ in E39CA. Positive trends in $\mathrm{NO}_{\mathrm{x}}$ in the lower stratosphere are about 4 times stronger than in NIWA-SOCOL, explaining the strong ozone decrease induced by the $\mathrm{NO}_{\mathrm{x}}$ destruction cycles. Furthermore, the $\mathrm{NO}_{\mathrm{x}}$ trends are identical in the two hemispheres in E39CA, and consequently also the hemispheric differences in chemicallyinduced ozone trends are much smaller compared to NIWASOCOL. Since in E39CA, $\mathrm{NO}_{\mathrm{y}}\left(=\mathrm{NO}_{\mathrm{x}}+\mathrm{HNO}_{3}\right)$ concentrations are prescribed at the upper level at $10 \mathrm{hPa}$, and concentrations are assumed to increase at the same rate as $\mathrm{N}_{2} \mathrm{O}$, any influence of changes in temperature and dynamics on $\mathrm{NO}_{\mathrm{y}}$ production is not accounted for. Thus, the impact of dynamical and temperature changes on $\mathrm{NO}_{\mathrm{x}}$ concentrations can be concluded to be crucial for both the response of ozone to $\mathrm{N}_{2} \mathrm{O}$ changes, in agreement with earlier studies (Plummer et al., 2010; Revell et al., 2012b), and the hemispheric asymmetry of ozone trends, as the results of this study suggest.

\subsubsection{Lower stratosphere: $\mathrm{Cl}_{\mathrm{y}}$ destruction cycles}

Changes in the efficiency of $\mathrm{Cl}_{\mathrm{y}}$ to deplete ozone is found to be one of the causes for hemispheric asymmetries in ozone trends. Enhanced efficiencies are found in the SH, where an expansion or shift of the polar vortex provides the conditions for heterogeneous ozone depletion in midwinter north of $60^{\circ} \mathrm{S}$. This effect was noted earlier for southern polar ozone, for example by Plummer et al. (2010), who found a nonlinearity of the response of ozone to ODSs in the Antarctic lower stratosphere under changing GHG concentrations. Similarly, Revell et al. (2012a) reported an increase of Antarctic lower stratospheric ozone in a scenario with lower GHG concentration increases as compared to the standard REF-B2 simulation. The results presented here suggest that the effect of GHG-induced cooling on homogenous ozone depletion is of importance in particular for the evolution of ozone in the mid-latitudes.

The trend analysis of the ensemble of CCMs reveals negative trends in SH mid-latitude ozone around 70 to $50 \mathrm{hPa}$ in about half of the models, indicating that the effect of an increasing efficiency of destruction by $\mathrm{Cl}_{\mathrm{y}}$ chemistry is of importance not only in NIWA-SOCOL. The strength of this effect will depend strongly on the pattern of dynamical changes, in particular in the location and timing of the
Antarctic vortex, simulated in each individual model. Thus, the variety of the simulated changes in the polar vortex likely accounts at least in part for the spread in the ozone trends and thus ozone return dates simulated by the different models.

\section{Conclusions}

The detailed investigation of mid-latitude return dates of TOZ to 1980 values from an ensemble of twelve CCMVal models, with particular focus on the hemispheric differences, confirmed recent studies (e.g. WMO, 2011) in that the earlier return date in the northern mid-latitudes compared to the southern mid-latitudes is a robust result. However, we found that there are large differences between individual models, with hemispheric return date differences ranging from about 0 to $30 \mathrm{yr}$ for TOZ. The method used to estimate the return dates can cause deviations of the results for the hemispheric difference in return dates of up to 5 to $10 \mathrm{yr}$ for individual models. Although results for individual models slightly depend on the applied method, the multi-model mean is barely affected by the method used.

Return dates in both hemispheres occur earlier than would be expected from the return of $\mathrm{Cl}_{\mathrm{y}}$ to 1980 levels. The forward shift is caused by positive linear trends in ozone. This forward shift is larger in the NH than in the SH because (i) the effect of a certain linear trend on the return date depends on the sensitivity of ozone to $\mathrm{Cl}_{\mathrm{y}}$, and (ii) the trend in ozone is stronger in the $\mathrm{NH}$ than in the $\mathrm{SH}$.

As summarized in Fig. 16, the hemispheric differences in total column return dates are due to differences in the evolution of ozone in the lower stratosphere and lowermost stratosphere/troposphere. Based on the models NIWA-SOCOL and E39CA, processes driving hemispheric differences in return dates are identified. The key result of this study is that changes in chemical production and loss play the major role in driving hemispheric differences in ozone return dates. The statement in WMO (2011) that the "more pronounced strengthening of the poleward transport of ozone" is the cause of the earlier return of ozone in the $\mathrm{NH}$ could not be confirmed in the present study. The chemically-induced changes identified in the lower stratosphere are, however, likely indirectly influenced by asymmetric BDC changes, which influence transport of ozone precursors - the rate at which these are produced by photolysis and temperatures that affect reaction rates. In particular, the main chemical processes identified here are the relatively less efficient destruction of ozone by $\mathrm{NO}_{\mathrm{x}}$ chemistry in the $\mathrm{NH}$, caused by likely dynamical influences on $\mathrm{NO}_{\mathrm{x}}$ concentrations, and the relatively more efficient destruction of ozone by $\mathrm{Cl}_{\mathrm{y}}$ in the SH due to an expansion of the polar vortex into mid-latitudes in midwinter.

Furthermore, ozone trends in the lowermost stratosphere and troposphere are found to contribute significantly to the hemispheric asymmetry in TOZ return dates. Enhanced 
production of ozone due to increasing $\mathrm{NO}_{\mathrm{x}}$ emissions are identified to introduce the hemispheric asymmetries in ozone trends. Since tropospheric chemistry is treated in a simplified manner in the CCMs used here, studies with improved representations of tropospheric chemistry will be necessary to validate this result. Overall it can be concluded that the uncertainties introduced by the treatment of tropospheric chemistry and ozone precursor emissions are not negligible for the correct simulation of the temporal development of TOZ.

\section{Appendix A}

\section{Methods of return date estimation}

To test the sensitivity of ozone return dates to the method used for their estimation, three different methods are intercompared:

1. Simple regression model

A linear least squares regression of the form

$$
\mathrm{O}_{3}(t)=a_{0}+a_{1} \times \mathrm{Cl}_{\mathrm{y}}(t)+a_{2} \times t+R(t)
$$

is applied to the annual mean ozone time series from $t=1960$ to 2049 . $\mathrm{Cl}_{\mathrm{y}}$ mixing ratios at $50 \mathrm{hPa}$ and at the same latitude as the ozone time series are used as the basis function. $a_{0}, a_{1}$ and $a_{2}$ are the offset, the $\mathrm{Cl}_{\mathrm{y}}$ and the trend regression coefficients, respectively, and $R$ is the residual. The uncertainties on the regression coefficients are calculated taking auto-correlation into account.

2. Regression model with quadratic terms

Again a linear regression model is used, but including $\mathrm{Cl}_{\mathrm{y}}$ and trend terms that are quadratic in $\mathrm{Cl}_{\mathrm{y}}$ and $t$ :

$\mathrm{O}_{3}(t)=a_{0}+a_{1} \times \mathrm{Cl}_{\mathrm{y}}(t)+a_{2} \times \mathrm{Cl}_{\mathrm{y}}(t)^{2}+a_{3} \times t+a_{4} \times t^{2}+R(t)$.

These additional terms allow for more degrees of freedom in the fitted time series, but a physical interpretation of the attributed variance is no longer straightforward.

3. Smoothing with a $1: 2: 1$ filter

A $1: 2: 1$ filter is applied iteratively to the ozone time series 20 times. The number of iterations of applying the filter is chosen as to obtain a smooth time series from which variability in the interannual to decadal time scale is removed but the long-term signal is maintained.

For methods 1 and 2, uncertainties on the return dates are calculated based on the uncertainty on the regression fit. The regression model uncertainties are estimated using a bootstrap procedure: first, the regression model is run on the original time series, obtaining the smooth regression fit and the residuals (original data minus fit). Then, a set of 10000 perturbed time series are constructed by adding noise to the regression fit. The added noise is generated by randomly selecting, with replacement, from the residuals. The regression model is fitted to each of the 10000 time series, and for each the return date is estimated. The error bars shown in Fig. 1 are then one standard deviation over these 10000 return date estimates.

Differences in estimated multi-model mean return dates between the three methods are significantly smaller than the return date differences between models (Fig. 1). The simple regression (method 1) yields a multi-model mean return date in the $\mathrm{NH} \sim 3 \mathrm{yr}$ earlier than the other two methods, but otherwise the agreement is good. For each individual model, however, the differences in return dates can be 5 to $10 \mathrm{yr}$, depending on the method used. Our results and those of SPARC-CCMVal (2010) (see their Fig. 9, p. 49) suggest that using different methods for deriving return dates will not bias the multi-model results, but only return date estimates for individual models. This suggests that the differences in the estimates from various methods are caused by the large amount of variability in the individual model time series, adding ambiguity to the retrieval of the signal.

Acknowledgements. We acknowledge the modeling groups for making their simulations available for this analysis, the ChemistryClimate Model Validation (CCMVal) Activity for WCRP's (World Climate Research Programme) SPARC (Stratospheric Processes and their Role in Climate) project for organizing and coordinating the model data analysis activity, and the British Atmospheric Data Center (BADC) for collecting and archiving the CCMVal model output. This study was funded by the Deutsche Forschungsgemeinschaft (DFG) through the DFG-research group SHARP (Stratospheric Change And its Role for climate Prediction) and by the New Zealand Foundation for Research Science and Technology and the Ministry of Science and Innovation. We would also like to thank G. Zeng for making UCAM tropospheric model data freely available for discussions and advice, and R. Deckert and L. Revell for comments on the manuscript.

Edited by: H. Wernli

\section{References}

Austin, J., Scinocca, J., Plummer, D., Oman, L., Waugh, D., Akiyoshi, H., Bekki, S., Braesicke, P., Butchart, N., Chipperfield, M., Cugnet, D., Dameris, M., Dhomse, S., Eyring, V., Frith, S., Garcia, R., Garny, H., Gettelman, A., Hardiman, S. C., Kinnison, D., Lamarque, J., Mancini, E., Marchand, M., Michou, M., Morgenstern, O., Nakamura, T., Pawson, S., Pitari, G., Pyle, J., Rozanov, E., Shepherd, T., Shibata, K., Stolarski, R., Teyssedre, H., Wilson, R., and Yamashita, Y.: The decline and recovery of total column ozone using a multimodel time series analysis, J. Geophys. Res., 115, D00M10, doi:10.1029/2010JD013857, 2010. 
Butchart, N., Cionni, I., Eyring, V., Waugh, D. W., Akiyoshi, H., Austin, J., Bruehl, C., Chipperfield, M. P., Cordero, E., Dameris, M., Deckert, R., Frith, S. M., Garcia, R. R., Gettelman, A., Giorgetta, M. A., Kinnison, D. E., Li, F., Manzini, E., McLandress, C., Pawson, S., Pitari, G., Rozanov, E., Sassi, F., Shepherd, T. G., Shibata, K., and Tian, W.: Chemistry-climate model simulations of twenty-first century stratospheric climate and circulation changes, J. Climate, 23, 5349-5374, 2010.

Cook, P. A. and Roscoe, H. K.: Changes in reactive stratospheric gases due to a change in Brewer-Dobson circulation: results from a simple model, Atmos. Sci. Lett., 13, 49-54, 2012.

Dameris, M., Grewe, V., Ponater, M., Deckert, R., Eyring, V., Mager, F., Matthes, S., Schnadt, C., Stenke, A., Steil, B., Brühl, C., and Giorgetta, M. A.: Long-term changes and variability in a transient simulation with a chemistry-climate model employing realistic forcing, Atmos. Chem. Phys., 5, 2121-2145, doi:10.5194/acp-5-2121-2005, 2005.

Egorova, T., Rozanov, E., Zubov, V., and Karol, I.: Model for investigating ozone trends (MEZON), Izv. Atmos. Ocean. Phys., 39, 277-292, 2003.

Eyring, V., Chipperfield, M., Giorgetta, M., Kinnison, D. E., Manzini, E., Matthes, K., Newman, P., Pawson, S., Shepherd, T., and Waugh, D.: Overview of the new CCMVal reference and sensitivity simulations in support of upcoming ozone and climate assessments and planned SPARC CCMVal, SPARC Newsletter, 30, 20-26, 2008.

Eyring, V., Cionni, I., Bodeker, G. E., Charlton-Perez, A. J., Kinnison, D. E., Scinocca, J. F., Waugh, D. W., Akiyoshi, H., Bekki, S., Chipperfield, M. P., Dameris, M., Dhomse, S., Frith, S. M., Garny, H., Gettelman, A., Kubin, A., Langematz, U., Mancini, E., Marchand, M., Nakamura, T., Oman, L. D., Pawson, S., Pitari, G., Plummer, D. A., Rozanov, E., Shepherd, T. G., Shibata, K., Tian, W., Braesicke, P., Hardiman, S. C., Lamarque, J. F., Morgenstern, O., Pyle, J. A., Smale, D., and Yamashita, Y.: Multi-model assessment of stratospheric ozone return dates and ozone recovery in CCMVal-2 models, Atmos. Chem. Phys., 10, 9451-9472, doi:10.5194/acp-10-9451-2010, 2010.

Garny, H., Dameris, M., and Stenke, A.: Impact of prescribed SSTs on climatologies and long-term trends in CCM simulations, Atmos. Chem. Phys., 9, 6017-6031, doi:10.5194/acp-9-6017-2009, 2009

Garny, H., Grewe, V., Dameris, M., Bodeker, G. E., and Stenke, A.: Attribution of ozone changes to dynamical and chemical processes in CCMs and CTMs, Geosci. Model Dev., 4, 271-286, doi:10.5194/gmd-4-271-2011, 2011.

Gettelman, A., M., Hegglin, I., Son, S.-W., Kim, J., Fujiwara, M., Birner, T., Kremser, S., Rex, M., Anel, J. A., Akiyoshi, H., Austin, J., Bekki, S., Braesike, P., Brühl, C., Butchart, N., Chipperfield, M., Dameris, M., Dhomse, S., Garny, H., Hardiman, S. C., Jöckel, P., Kinnison, D. E., Lamarque, J. F., Mancini, E., Marchand, M., Michou, M., Morgenstern, O., Pawson, S., Pitari, G., Plummer, D., Pyle, J. A., Rozanov, E., Scinocca, J., Shepherd, T. G., Shibata, K., Smale, D., Teyssedre, H., and Tian, W.: Multi-model assessment of the upper troposphere and lower stratosphere: tropics and global trends, J. Geophys. Res., 115, D00M08, doi:10.1029/2009JD013638, 2010.

Grewe, V.: Impact of climate variability on tropospheric ozone, Sci. Total Environ., 374, 167-181, 2007.
Hein, R., Dameris, M., Schnadt, C., Land, C., Grewe, V., Köhler, I., Ponater, M., Sausen, R., B. Steil, B., Landgraf, J., and Brühl, C.: Results of an interactively coupled atmospheric chemistry - general circulation model: Comparison with observations, Ann. Geophys., 19, 435-457, doi:10.5194/angeo-19-435-2001, 2001.

Land, C., Feichter, J., and Sausen, R.: Impact of vertical resolution on the transport of passive tracers in the ECHAM4 model, Tellus B, 54, 344-360, 2002.

Lelieveld, J. and Dentener, F. J.: What controls tropospheric ozone? J. Geophys. Res., 105, 3531-3551, 2000.

Montzka, S. A., Butler, J. H., Elkins, J. W., Thompson, T. M., Clarke, A. D., and Lock, L. T.: Present and future trends in the atmospheric burden of ozone-depleting halogens, Nature, 398, 690-694, 1999.

Morgenstern, O., Giorgetta, M. A., Shibata, K., Eyring, V., Waugh, D. W., Shepherd, T. G., Akiyoshi, H., Austin, J., Baumgaertner, A. J. G., Bekki, S., Braesicke, P., Brühl, C., Chipperfield, M. P., Cugnet, D., Dameris, M., Dhomse, S., Frith, S. M., Garny, H., Gettelman, A., Hardiman, S. C., Hegglin, M. I., Jöckel, P., Kinnison, D. E., Lamarque, J., Mancini, E., Manzini, E., Marchand, M., Michou, M., Nakamura, T., Nielsen, J. E., Olivié, D., Pitari, G., Plummer, D. A., Rozanov, E., Scinocca, J. F., Smale, D., Teyssèdre, H., Toohey, M., Tian, W., and Yamashita, Y.: Review of the formulation of present-generation stratospheric chemistry-climate models and associated external forcings, J. Geophys. Res., 115, D00M02, doi:10.1029/2009JD013728, 2010

Oltmans, S., Lefohn, A., Shadwick, D., Harris, J., Scheel, H., Galbally, I., Tarasick, D., Johnson, B., Brunke, E.-G., Claude, H., Zeng, G., Nichol, S., Schmidlin, F., Davies, J., Cuevas, E., Redondas, A., Naoe, H., Nakano, T., and Kawasato, T.: Recent tropospheric ozone changes - A pattern dominated by slow or no growth, Atmos. Environ., 67, 331-351, doi:10.1016/j.atmosenv.2012.10.057, 2013.

Oman, L. D., Plummer, D., Waugh, D., Austin, J., Scinocca, J., Douglass, A., Salawitch, R., Canty, T., Akiyoshi, H., Bekki, S., Braesicke, P., Butchart, N., Chipperfield, M., Cugnet, D., Dhomse, S., Eyring, V., Frith, S., Hardiman, S., Kinnison, D., Lamarque, J., Mancini, E., Marchand, M., Michou, M., Morgenstern, O., Nakamura, T., Nielsen, J., Olivie, D., Pitari, G., Pyle, J., Rozanov, E., Shepherd, T., Shibata, K., Stolarski, R., Teyssedre, H., Tian, W., and Yamashita, Y.: Multi-model assessment of the factors driving stratospheric ozone evolution over the 21st century, J. Geophys. Res., 115, D24306, doi:10.1029/2010JD014362, 2010

Plummer, D. A., Scinocca, J. F., Shepherd, T. G., Reader, M. C., and Jonsson, A. I.: Quantifying the contributions to stratospheric ozone changes from ozone depleting substances and greenhouse gases, Atmos. Chem. Phys., 10, 8803-8820, doi:10.5194/acp-108803-2010, 2010

Portmann, R. W. and Solomon, S.: Indirect radiative forcing of the ozone layer during the 21st century, Geophys. Res. Lett., 34, L02813, doi:10.1029/2006GL028252, 2007.

Reithmeier, C. and Sausen, R.: ATTILA: atmospheric tracer transport in a Lagrangian model, Tellus B, 54, 278-299, 2002.

Revell, L. E., Bodeker, G. E., Huck, P. E., and Williamson, B. E.: Impacts of the production and consumption of biofuels 
on stratospheric ozone, Geophys. Res. Lett., 39, L10804, doi:10.1029/2012GL051546, 2012a.

Revell, L. E., Bodeker, G. E., Smale, D., Lehmann, R., Huck, P. E., Williamson, B. E., Rozanov, E., and Struthers, H.: The effectiveness of $\mathrm{N}_{2} \mathrm{O}$ in depleting stratospheric ozone, Geophys. Res. Lett., 39, L15806, doi:10.1029/2012GL052143, 2012 b.

Rosenfield, J. and Douglass, A.:, Doubled $\mathrm{CO}_{2}$ effects on $\mathrm{NO}_{\mathrm{y}}$ in a coupled 2D model, Geophys. Res. Lett., 25, 4381-4384, 1998.

Rosenfield, J. E., Douglass, A. R., and Considine, D.: The impact of increasing carbon dioxide on ozone recovery, J. Geophys. Res., 107, D64049, doi:10.1029/2001JD000824, 2002.

Schraner, M., Rozanov, E., Schnadt Poberaj, C., Kenzelmann, P., Fischer, A. M., Zubov, V., Luo, B. P., Hoyle, C. R., Egorova, T., Fueglistaler, S., Brönnimann, S., Schmutz, W., and Peter, T.: Technical Note: Chemistry-climate model SOCOL: version 2.0 with improved transport and chemistry/microphysics schemes, Atmos. Chem. Phys., 8, 5957-5974, doi:10.5194/acp-8-59572008, 2008.

Scinocca, J. F., Stephenson, D. B., Bailey, T. C., and Austin, J.: Estimates of past and future ozone trends from multimodel simulations using a flexible smoothing spline methodology, J. Geophys. Res., 115, D00M12, doi:10.1029/2009JD013622, 2010.

Solomon, S.: Stratospheric ozone depletion: A review of concepts and history, Rev. Geophys., 37, 275-316, 1999.

SPARC-CCMVal: SPARC Report on the Evaluation of ChemistryClimate Models, edited by: Eyring, V., Shepherd, T. G., and Waugh, D. W., SPARC Report No. 5, Tech. Rep., WCRP-132, WMO/TD-No. 1526, available at: http://www.sparc-climate.org/ publications/sparc-reports/sparc-report-no5/, 2010.

Steil, B., Dameris, M., Brühl, C., Crutzen, P. J., Grewe, V., Ponater, M., and Sausen, R.: Development of a chemistry module for GCMs: first results of a multiannual integration, Ann. Geophys., 16, 205-228, doi:10.1007/s00585-998-0205-8, 1998.

Stenke, A. and Grewe, V.: Simulation of stratospheric water vapor trends: impact on stratospheric ozone chemistry, Atmos. Chem. Phys., 5, 1257-1272, doi:10.5194/acp-5-1257-2005, 2005.
Stenke, A., Dameris, M., Grewe, V., and Garny, H.: Implications of Lagrangian transport for simulations with a coupled chemistry-climate model, Atmos. Chem. Phys., 9, 5489-5504, doi:10.5194/acp-9-5489-2009, 2009.

Stevenson, D. S., Dentener, F. J., Schultz, M. G., Ellingsen, K., van Noije, T. P. C., Wild, O., Zeng, G., Amann, M., Atherton, C. S., Bell, N., Bergmann, D. J., Bey, I., Butler, T., Cofala, J., Collins, W. J., Derwent, R. G., Doherty, R. M., Drevet, J., Eskes, H. J., Fiore, A. M., Gauss, M., Hauglustaine, D. A., Horowitz, L. W., Isaksen, I. S. A., Krol, M. C., Lamarque, J., Lawrence, M. G., Montanaro, V., Müller, J., Pitari, G., Prather, M. J., Pyle, J. A., Rast, S., Rodriguez, J. M., Sanderson, M. G., Savage, N. H., Shindell, D. T., Strahan, S. E., Sudo, K., and Szopa, S.: Multimodel ensemble simulations of present-day and near-future tropospheric ozone, J. Geophys. Res., 111, D08301, doi:10.1029/2005JD006338, 2006.

WMO: Scientific Assessment of Ozone Depletion: 2010, Tech. rep., Global Ozone Research and Monitoring Project-Report No. 52, Geneva, Switzerland, 516 pp., 2011.

Wuebbles, D. J. and Hayhoe, K.: Atmospheric methane and global change, Earth-Sci. Rev., 57, 177-210, 2002.

Young, P. J., Archibald, A. T., Bowman, K. W., Lamarque, J.-F., Naik, V., Stevenson, D. S., Tilmes, S., Voulgarakis, A., Wild, O., Bergmann, D., Cameron-Smith, P., Cionni, I., Collins, W. J., Dalsøren, S. B., Doherty, R. M., Eyring, V., Faluvegi, G., Horowitz, L. W., Josse, B., Lee, Y. H., MacKenzie, I. A., Nagashima, T., Plummer, D. A., Righi, M., Rumbold, S. T., Skeie, R. B., Shindell, D. T., Strode, S. A., Sudo, K., Szopa, S., and Zeng, G.: Preindustrial to end 21 st century projections of tropospheric ozone from the Atmospheric Chemistry and Climate Model Intercomparison Project (ACCMIP), Atmos. Chem. Phys., 13, 2063 2090, doi:10.5194/acp-13-2063-2013, 2013. 